\title{
IRISH FILM AND TELEVISION - 2009
}

\section{The Year in Review \\ Tony Tracy (ed.)}

Irish Film and Television Review 2009. Introduction

Tony Tracy

Myth and Murder in The Daisy Chain

Zélie Asava

Troubles Cinema: Five Minutes of Heaven \& Fifty Dead Men Walking

Ruth Barton

“Looking at the Stars": TV3 adapts Lady Windermere's Fan

Liam Burke

Masks and Faces: Identities

Dennis Condon

Being Digital - Irish cinema and digital production

Roddy Flynn

The Yellow Bittern

Robert Furze

Donal Donnelly: An Appreciation

Michael Patrick Gillespie

Sketching Success: Brown Bag Films go to the Oscars

Sinead Gillett

Helen

Padraig Killeen

Ondine

Paul McGuirk

Pure Mule, The Last Weekend: The Finite Televisual Narrative

Barry Monahan

This Sporting Life: Recent Irish sports documentaries

Harvey O’Brien 250

Savage Sounds

Maria O’Brien 253

Copyright (c) 2010 by the authors. This text may be archived and redistributed both in electronic form and in hard copy, provided that the authors and journal are properly cited and no fee is charged for access.

ISSN 1699-311X 


\section{Irish Film and Television 2009}

\section{Tony Tracy}

At the launch of the 2008 annual Irish Film Board Review - complete with flowing wine, a lavish publication and complementary DVD compilation (Irish Talent on Film Vol. V) - CEO Simon Perry, still recalling the success of Once stated that there had never been a better time for Irish cinema. There had never been so many coproductions in the pipeline, films in development, in production or about to be released. In spite of such ebullience, 2009 didn't in reality feel like a Golden Age for Irish cinema and we were denied the opportunity to hear the Irish Film Board's current prognosis of the industry as, in keeping with the new culture of public sector austerity, there was neither launch, publication nor DVD compilation in late 2009. That there is still a Irish Film Board is something of a miracle in itself, for it has been a year of prolonged economic and cultural (not to mention environmental) shocks in Ireland that resulted in unprecedented curtailments of public spending a situation comparable to the one that brought about the premature disbanding of the first Irish Film Board in 1987. To understand why this action wasn't repeated involves consideration of a number of factors including changes in the globalization of the culture industry and Ireland's place in it, the cultural and psychic legacy of the confidence engendered by the Celtic Tiger years, the elaborate and extensive infrastructure (education, training, facilities, equipment) that grew up around the audiovisual and cultural sector during the good times, the international success of Irish cultural producers in film, music, drama and literature most notably - over the past two decades, and the awareness of the value of an "indigenous" Irish culture in an increasingly multicultural society and open economy. A hugely significant factor however, was how sophisticated the sector itself has become in arguing its own case for sustained state support.
Too late for inclusion in last year's review was mention of the 2008 PricewaterhouseCoopers report commissioned by The Irish Film Board "to inform a new landmark strategic plan for the audiovisual content production sector." report was valuable on many fronts, not least because it refreshed statistics that were well out of date, but especially because it increased the scope of its findings beyond the bald production data of earlier reports to consider the "real economy" of the industry. Thus we discovered that "the sector is valued at over $€ 557.3$ million, employs over 6,000 individuals and represents $0.3 \%$ of Gross Domestic Product (GDP)". We also learnt that the sector employs 6,905 individuals and that an estimated 567 companies operate comprising production companies, postproduction companies and service providers. There is provocative and real detail in the findings on "freelancers" - a sizable bulk of the industry: that $90 \%$ are under the age of 50 and the majority are male, with earnings between $€ 2,500$ and $€ 150,000$ in 2006 and 2007. Freelancers are "a well educated group with 59\% having achieved either a Degree, Master/ Postgraduate Degree or Doctorate/ Post Doctoral Degree - only $2 \%$ of freelancers have no formal qualification at all.” For all the emphasis on, and attention garnered by feature film production, the report notes that the area of post-production has experienced the largest growth in recent years with a sizable proportion of employees earning $€ 35,000$ per annum. Here then is objective evidence of the much vaunted "knowledge economy" - the buzz concept at the heart of much recent Government discussions on education and future growth - or the basis of it.

The depth and subtlety of the report was always

1. http://www.filmboard.ie/files/Final\%20Audio Visual\%20Sector\%20Survey\%20Report-1.pdf. 
going to be useful in informing future strategy but as the 2009 progressed it became, literally, vital. In a bid to stop the haemorrhaging of public money in the aftermath of a spectacular collapse in tax receipts, the government appointed economist Colm McCarthy to chair a committee (aka "an Bord Snip Nua") charged with identifying where savings might be made. The resulting, "McCarthy Report" (published in July 2009 and properly titled "Report of the Special Group on Public Service Numbers and Expenditure Programmes") was broad-ranging and cold-eyed in its targets. In relation to the IFB it proposed that “ $\ldots$ sector-specific agencies such as the Irish Film Board, should be merged within a re-constituted Enterprise Ireland.” It argued that "The discontinuation of Irish Film Board and investment fund" would garner savings of some $€ 20$ millions. The logic of this action was based upon the premise that the IFB was fundamentally an "enterprise activity" - along with organizations such as Bord Iascaigh Mhara, Bord Bia (the fish board and food board respectively) - that "sold" Ireland at home and principally abroad. It was a daft misunderstanding of the board's activities but nonetheless its argument for consolidation was one being applied across a range of public bodies and "qangos" (quasi non-governmental organizations), which proliferated in time of financial plenty.

The IFB responded, speaking the language of the economists:

The funding provided through BSÉ/IFB attracts additional finance that today supports an increasing level of private sector employment. The growth potential of the audiovisual content industry, as an essential component of the Smart Economy strategy, represents one of the best prospects of employment for young people seeking jobs in the future. For these reasons we believe it is important, in the context of the immediate crisis in the public finances, to ask Government to consider carefully the economic impact and employment consequences of this particular recommendation.

And consider it, the government did. To the surprise and delight of many, McCarthy's myopic view of the function, significance and indeed economics of indigenous film was quickly rejected by Minister for Arts Sport and Tourism Martin Cullen, who said that "earmarking the Irish Film Board for closure was an 'horrific approach"”: He had fought to keep the 100 per cent tax exemption last year because it helped to generate a $€ 150$ million industry; Both the IFB and "Culture Ireland", which promotes and advance Irish arts internationally, generated "far, far greater return" for the State than the money put into it in the first place. Elsewhere, far from simply defending the value and importance of the arts to a society at large, Cullen suggested that the cultural sector would become central to Ireland's future economic policies:

Culture is really at the centre of what we're going to do going forward ... It's the biggest growth area, in spite of the world downturn, that's going to come over the next 15 years.

In fact, so foregrounded were economic arguments in defence of the film sector that any trace of intrinsic merit seemed a secondary consequence, at best. Even when the IFB seemed to summon "soft" values in defence of its continued existence,

To be taken into consideration also are the consequences for Ireland if it were to become the only developed country in the world producing no films for the cinema, and thereby losing the most powerful tool available for establishing and sustaining its cultural identity abroad ...

it quickly reassured the Minister for Finance: "Almost one in two US tourists to Ireland now state that their decision to come was triggered by seeing Ireland in the movies." Never mind that most of those movies were likely made long before the existence of the second film board. The perception of the IFB as primarily an artistic - rather than marketing - institution was bolstered by Neil Jordan in a provocative comment that quickly became a rallying point for the wider arts community: "So many institutions have failed the Irish people . . . the banks, the construction industry, the Church [but] The culture industry, they have not failed, they are perhaps the only success story that remains after the last 20 years."

That comment was made outside Farmleigh House (Phoenix Park) in the aftermath of a 
diaspora "think-in” proposed by "popeconomist” David McWilliams. A kind of Davos in Dublin, this weekend of behind-doors talking amongst the elite of Irish men and women from around the globe seemed to generate just one specific recommendation to remedy our financial woes. Martin Cullen and billionaire financier Dermot Desmond proposed the establishment of a world class arts and culture university, to better "monatise" (in the words of telecoms businessman Dennis O’Brien) our national culture. The knock-on of all this enthusiasm for culture as a key provider for future revenue, growth, value to tourism and "brand Ireland" is that the IFB experienced a mere 5\% drop in its overall funding; a remarkably benign reduction in the circumstances.

On the face of it, Simon Perry was correct: 2009 was an unprecedented period of activity in terms of feature film completions. We count some fourteen titles: Five Minutes of Heaven (Oliver Hirschbiegel), The Eclipse (Conor McPhearson) His and Hers (Ken Wardrop), Savage (Brendan Muldowney), Occi Versus the World (Conor McDermottroe) (aka Swansong: Story of Occi Byrne), One Hundred Mornings (Conor Horgan), The Wake Wood (David Keating) Eamon (Margaret Corkery), Zonad, Cherrybomb, Perrier's Bounty, Wide Open Spaces (Tom Hall) Happy Ever Afters (Stephen Burke), and "independent features" (ie made without direct IFB funding by Park Pictures) Situations Vacant (Lisa Mulcahy) and Ivan Kavanagh's Fading Light. Few of these were the straightforward production finance arrangements that used to be the norm of Irish cinema. While all but the Park Pictures films were supported by the Irish Film Board, all are co-productions, with Film Board funding central only to the $€ 150,000$ budgets of the Catalyst films (Eamon, One Hundred Mornings and the forthcoming Redux) and its various short film and animation schemes.

There were also a number of other coproductions whose provenance and centrality to a discussion of national cinema is less easy to define - films like Danis Tanovic's Triage (starring Colin Farrell), Vic Sarin's A Shine of Rainbows (starring Aidan Quinn), Urszula Antoniak's Nothing Personal (starring Stephen
Rea), Mira Fornay's Foxes - all of which are coproduced with east European partners, none of which have been seen here and all of which appear - on the bases of supplied synopses - to use Ireland opportunistically as a co-production location or production partner. Of course, the casting of Irish actors complicates a reductive reading of these east-west co-productions as simply marriages of financial convenience and time will tell if in them, we find the seeds of an enlarged understanding of Irish cinema. Finally, the largest budget of any film made in Ireland in 2009 was for the Hollywood "rom-com" Leap Year, the latest in the century old tradition of American cinema to consider Ireland less of a geographical than imaginary entity; a backward idyll where over-worked Americans can escape the pressures of consumer capitalism and recover their inner romantic in a pastoral landscape untrammelled by worldly success. Ironic, given the state of our economy.

However, despite this impressive roster of activity and the dedication to maximizing output by the IFB, this year's review is somewhat thin in its traditional attention to feature titles since so many films remain unreleased while others have had short releases or been confined to the film festival circuit. While some made it to the traditional showcase of new Irish film at the Galway Film Fleadh in July 09 - His and Hers, Savage, Occi Versus the World, One Hundred Mornings and Zonad - all have yet to be seen by wider audiences. At time of writing, the biggest indigenous film of the year, Neil Jordan's Ondine has also yet to find a release. Here, then, are some first impressions ...

His and Hers is the feature debut of Ken Wardrop, a singular voice in Irish cinema. After its Galway premiere, it achieved international recognition with its acceptance into the Sundance Film Festival (Jan 2010) where it was widely praised in the American trade press and won the "World Cinema Documentary Cinematography Prize"; a considerable achievement for a film of its budget and scope. With his producing partner and recent National Film School co-graduate Andrew Freedman, Wardrop has made eleven short films principally "creative documentaries" which have already - quite exceptionally - been the subject 
of a retrospective at the Irish Film Institute in 2008. Watching those sometimes slight though engaging films one wondered how Wardrop would parlay a highly individual perspective into a longer format. His and Hers is a convincing and organic extrapolation of his method and style in its delicate realism and deep respect for his subjects. Wardrop may be making documentaries but they are neither the "creative treatment of actuality" specified by Grierson nor the straightforward expository storytelling format however poetic - familiar from Irish TV. His sensibility is tuned particularly towards the feminine and the 'taken-for-granted' of daily life and this film follows the life cycle of a group of some 70 women from the Irish midlands - a middle space in more senses than one and one largely absent in Irish cinema which has tended to gravitate to the coasts in search of the essence of Irishness. This choice of subject and setting marks the film as simultaneously marginal and (geographically, biologically) central and returns us, after the international capitalism of the lad dominated Tiger years, to a more enduring Ireland guided by a feminine animus. The cyclical motif is central to the film's structure which documents an unidentified group of women across all stages of their lives. A formal restraint cuts across a homely familiarity to produce a generalized, while unmistakably local portrait of Irish womanhood.

An original and promising talent is also on display in Eamon, the debut feature film by Margaret Corkery. This film was one of three funded by the IFB's innovative Catalyst scheme; a new funding mechanism inspired by the 'lowfi' success of Once that offers first-time filmmakers the comparatively tiny budget of $€ 150,000$ (by way of comparison, Leap Year was in the region of $\$ 20$ million). Despite this, Corkery and her collaborators have produced a satisfying if slight film that looks great and doesn't feel unduly limited by financial constraints. Eamon shares the mood and ambiance of Corkery's short Killing the Afternoon in its beach setting - an oddly unfamiliar location in Irish cinema given our island status. It centres on the title character, a small boy, and his relationship with his young, selfish and largely incompetent parents as they spend a few days away from Dublin in a holiday cottage. While the material might suggest the style of British directors like Shane Meadows or Lynn Ramsey, Corkery opts for a far gentler approach that both critiques the parents (effectively played by Darren Healy and Amy Kirwan) - gently satirizing their inability to progress beyond bodily self-indulgence - while offering us a warm and paradoxically nostalgic portrait of summer holidays by the sea. While some might fault the thinness of its plot or the refusal to take its serious subjects more seriously, Eamon has an idiosyncratic tone and strong cinematic voice that makes it distinctive and engaging.

Both His and Hers and Eamon are notable not only for their respective directors' strongly cinematic voices but to the extent which they deviate from trends in Irish cinema over the past decade: notably the preoccupation with urban masculinity in crisis and genre storytelling. This thematic nexus is found once again in Savage, an unsubtle but revealing revenge narrative which offers a very Irish take on the emasculated white male motif found in American cinema since Dirty Harry (which in turn gave rise to the raperevenge sub-genre). It follows the transformation of a shy press photographer (played once again by Darren Healy) into a blood thirsty avenger following an assault in Dublin city centre. Characterization is weak and the plot clunky and simplistic in this attempt to reflect changes in Irish society - here the exponential rise in knife violence and assault perpetrated by, and against, young men in our urban centres - through the filter of Hollywood genre practices. This recurrent tendency clearly reflects a cinematic "education" steeped in American film and an ambition to participate in an international cinematic vernacular based on "indigenous" story elements. While Savage displays an admirable desire to engage with the ongoing "crises" in Irish masculinity, the result is deadend film-making caught between a dated and obvious genre structure and a screenplay with little originality or skill. Where are all the script editors?

We have mentioned Once on several occasions in this overview and the disproportionate success of that film meant that whatever its writer/ 
director John Carney did next would be greeted with much anticipation and more than likely a decent budget. What was conveniently overlooked in the publicity surrounding the Once ("the little film that could") was that Carney had risen the slippery pole of success earlier in his career only to score a misfire when offered the opportunity of a bigger budget and better distribution. Having created a strong impression with his "no-budget" films of the mid-nineties, November Afternoon and Park (co-directed with Tom Hall) Carney went on to make On the Edge funded and distributed by Universal Pictures. It was a downbeat and unappealing story about teenage depressives and following it, Carney returned to his more improvisational style in the loose-limbed and libidinous TV series Bachelor's Walk (surely the most successful treatment of the "new" Irish male in recent times). This time, no doubt offered all kinds of projects in the aftermath of Once's success, Carney has instead followed with something completely different. Zonad (co-written with his brother Kieran) is like nothing seen in Irish cinema before: offbeat, lecherous and very funny. An exuberant pastiche of 1950s American sci-fi (with a terrifically inventive soundtrack to match) Zonad feels like The Butcher Boy meets American Pie and will surely find a loyal audience in 15-25 year old demographic when it eventually gets a release. Simon Delaney in the title role (as escaped convict who pretends to be an alien named Zonad) is particularly funny but his deception is sustained by the consistency of the film's tone across all areas of the production. What is most impressive is Zonad's knowing playing with cinematic history - including the ultimate Irish film of a male outsider who pursues the local girl, The Quiet Man - without ever pandering to that heritage or seeking to engage with it beyond pastiche.

This year's review contains entries on a wide range of output: documentary, features, TV as well as Michael Patrick Gillespie's timely tribute to the late Donal Donnelly. In 2009 the Irish audiovisual sector continued to demonstrate skill and success beyond its borders, notably in the area of animation (an impressive two Oscar nominations in 2010 and discussed below), short films and low-budget feature productions (with festival awards for Eamon and His and Hers). The sector provided employment and vital experience through a vibrant slate of coproductions as well as the large-scale projects Leap Year and the final (fourth) series of The Tudors at Ardmore Studios. With the improvement of terms for the "section 481" tax break during 2009, the sector's internationalization is only likely to increase. That this is now a cornerstone of Ireland's "business plan" for the sector is evidenced by the fact that The Tudors Irish producer Morgan O'Sullivan recently unveiled plans to construct a new film studio in Wicklow in order to pursue large-scale international co-productions. The weak spot in this patchwork of activity has been the central, expensive plank of indigenous feature film production which continues to disappoint. Scriptwriting skills remain below par and the IFB must assume some responsibility for not pushing the scripts, and writers they fund, harder. Distribution, as we've noted, is also an issue. Irish audiences are still attending the cinema in record numbers but, like their international counterparts, are going to see a narrow range of product at their local multiplexes. While the Hollywood behemoth Avatar becomes the biggest grossing film in history, Irish films are lucky to get a week on the schedule. This is by no means an issue specific to Ireland and indeed the rollout of digital projection has helped improve matters for some smaller films like Situations Vacant (a low budget feature entirely funded by TV3) that was released on an impressive nineteen screens. While Government support and commitment to the sector remains strong, the prospects for the production of "indigenous" Irish films above a budget range of $€ 2$ million (beyond Jordan or Sheridan) seem bleak, with consequences for story ambitions and production values. For now however, such funds as are available ought to be directed towards the rigorous development of scripts and young writers. There is still much work to be done.

Tony Tracy is Associate Director of the Huston School of Film and Digital Media, NUI Galway. 
Myth and Murder in The Daisy Chain (Aisling Walsh, 2009)

Zélie Asava

Aisling Walsh's latest film The Daisy Chain (Walsh 2008) is a complex exploration of the human potential for evil. Martha (Samantha Morton) and Tomas Conroy (Steven Mackintosh), an urbanite English couple, return to his birthplace in an isolated village on the west coast of Ireland to set up home. They take in Daisy Gahan (Mhairi Anderson), a child whose family has just died, even though locals suspect that she might be possessed by a demonic fairy changeling. Those who try to control the child or get close to her surrogate mother Martha, die. The villagers ostracise and try to kill the young girl, convinced she is a fairy and hoping to bring back the real child. The Daisy Chain explores the figure of the disturbed child as folk monster, alternately suggesting the child's antisocial behaviour as the result of autism, abuse or evil.

Mirroring life, the film is imbued with postCeltic Tiger notions on the importance of prioritising simple pleasures and community life, and the obsession with appropriating culpability for the problems with which we are faced. The problems of a small town are projected onto a girl who is viewed as a supernatural devil, responsible for the ills of a society too blind to see that it is they who have created them. It is a clear lesson for a society that often blames the media for the evils of children who kill and mame, and which is still coming to terms with a long history of institutional abuse.

Martha is undergoing a difficult pregnancy following the loss of her first baby through cot death. She attaches huge importance to caring for Daisy, perhaps because she is still mourning her child, perhaps because she recognises how much this troubled child needs love. If we read her through concepts such as the 'archaic mother' and the 'monstrous-feminine' (see Creed 1993), perhaps her own memories of hysteria and abuse give her the desire to open her heart to
Daisy. By contrast her husband rejects the child, perhaps out of jealousy, and yet his fears appear justified at the end of the film. The final sequence takes on an otherwordly nightmarefantasy element as the myths become 'real'. We see the fairy/child force Martha into birth and then take the baby for herself while Martha lies, presumably dead, in a pool of blood. Tomas takes the baby away and the film ends.

Here, as in Changeling (Eastwood 2008), missing children take on a supernatural quality, and the boundaries of truth and fiction are blurred. In Walsh's film Celtic notions compound the confusion as the child evokes pagan ideas of the changeling, a fairy who replaces a kidnapped child, identifiable by her screaming, estrangement and destructive actions. As Martha flicks through a fairy book for children early on in the film, it is clear to see the similarity between this elfin child Daisy and the mythical creatures. The film thus uses the power of suggestion to challenge our modern/Christian rejection of such elements and speaks to our subconscious, pre-historic suspicion that there's more here than meets the eye.

The trope of rural Ireland as the romantic or the sublime and the idea of the freedom of the wild is undermined here. Most scenes are filmed indoors in the cramped confines of a labourer's cottage, a doctor's surgery, a hospital waiting room. Once the locals come to the conclusion that Daisy is spreading disease and death, the police tell the family to send Daisy to an institution to be looked after by specialists, or risk their lives. This makes the great outdoors a place to fear and evade, and leaves the protagonists confined to an emotionally and physically claustrophobic space. The encircling imagery of the enclosed cottage, faced on one side by a murderous old man (who tries to kill the fairy), and on others by the wild west coast, 
evokes the mystery and tragedy of the remote space in which this drama unfolds. The theatrical tableau of the space is reinforced by the observational camerawork which both obscures and constructs our view of this world, just as the picturesque view of the rural is itself a construction.

The Daisy Chain draws on The Butcher Boy (Jordan 1997) in its use of horror tropes to illuminate the social neglect of a child in a rural community. As Martin McLoone (2000) controversially argues with regard to The Butcher Boy, Francie Brady (Eamonn Owens) may be taken to represent Ireland both as the abused child of history and as a place losing touch with its own identity where myth and reality blend into one and old values are lost. Just as Francie is disregarded as a "pig", and abandoned, Daisy is found living like an animal and treated as an unwanted stain on the community.

Like Exposure (Walsh 1978) - where a French woman's modern take on morality shakes up a rural town and results in her violation by three men obsessed with her - the film presents the foreign within the traditional Irish rural community as exciting, threatening, sexual, immoral and fatal. Martha's foreign modern outlook exists in opposition to her neighbours' superstitious fears and binaried perspective. She refuses to be fenced in by fear or fixed beliefs. Upon arrival in the cottage she takes down the crucifix above the bed which, from the difference in colour its absence reveals on the wall, appears never to have been removed before. She rejects the locals' impression of the girl as well as their attempts to send the girl to a home. She continues to visit and treat with affection the old man who lives next door despite the threat he poses to Daisy. Martha finds difference engaging while the locals find it troubling. Her outlook results in her demise.

The key themes of hybridity, impurity and loss in The Daisy Chain, also seen in rural-set Irish horror films such as Isolation (O'Brien 2005), Shrooms (Breathnach 2007) and Seer (Courtney 2008), can be read as expressions of the fear of difference, a fear which Gerardine Meaney sees as shaping the national identity as it navigates the overwhelming change in Ireland brought about by the recent boom years of immigration, economic growth, urban expansion and multiculturalism:

Irish 'identity' is it seems, poised between rational self-awareness and the deployment of historically produced paranoid localism in the interest of a highly accelerated techno-globalisation... If we are to proceed to accept the strange and the migrant as no more nor less than our shared conditions of being, then we must begin with an acknowledgement of the history of difference, (m)othering the nation (2007: 62).

Following the first significant wave of immigration in the late 1990s after the birth of the 'Celtic Tiger', the focus on alleged 'citizenship tourism' (having babies in Ireland to gain citizenship) resulted in a new Citizenship Act (2004) guaranteeing Irish nationality only to those with blood rights (see Garner 2007). This rejection of difference was centred on the nonwhite, non-European migrant and maintained the idea that there was a core Irish identity to protect. In The Daisy Chain, many myths of difference are dispelled; the foreign pregnant mother is white and European (an accurate racial reflection of the majority of migrants to Ireland), the cross-cultural history of Ireland is exposed in Martha and Tomas' productive union (also evoking the earlier hybridising efforts of the Normans and Danes), and the strange and different is abject but infantilised. Martha finds peace by (m)othering the nation, as Meaney suggested, through this fairy/child who blossoms once accepted. Yet, their unconditional love grows into an obsession and, although we never see Daisy commit a crime, her jealousy is clearly a factor in the many accidents that befall anyone who tries to get close to Martha. Walsh reinforces our suspicions about Daisy's powers by offering no alternative cause for the deaths that occur in this small community, thus placing us in the position of the fearsome locals.

Aisling Walsh is one of few Irish female filmmakers and the first to make an impact on the horror genre. Her work is preoccupied with the experience of the repressed, the migrant and the alien. Like The Daisy Chain, her last film, Song for a Raggy Boy (2003), focused on subjective interpretation, the foreigner within, and the need to articulate the truth of ourselves 
and our histories. In a sense both films are explorations of love, its effect on our memory, and its position as the source of our motivations. Her films centralise sexuality and religion, exploring the historical impetus of these culturally entwined elements on the Irish psyche, and in particular, the effect of the church on Irish masculinity.

Despite the prominence of women in The Daisy Chain, the father is in many ways the most identifiable character, recognisable as an everyman in his flaws and his fears. Although the spectator may wish to embody the heroic altruism of Martha and defend the weak, it is more likely that we would act like Tomas, remaining on the fence between her position and that of the majority, before allowing our jealousy to justify expelling the child. As Tomas becomes more and more obsessed with the loss of his wife he comes to mirror Daisy, wanting Martha all to himself. In this way Walsh's style veers away from key Irish female filmmakers such as Margo Harkin and Pat Murphy and bears more commonalities with the work of Chantal Akerman and specifically her 2000 film The Captive, in its exploration of male vulnerability, insecurity and obsession.

The Daisy Chain may be read as a response to the latest wave of Irish cinema, known as Celtic Tiger Cinema, which has focused on the new cultural focus on materialism and sex. Yet in concurrence with these films The Daisy Chain explicitly visualises the death of the old Ireland, while recalling its pre-Christian past and inherent hybridity. As Martin McLoone explains: 'The[se] films seem to suggest that Catholic, Nationalist Ireland is now merely a faded memory passed down to Ireland's young population from their grandparents (or, ironically gleamed from those Irish films that seem to be obsessed by this dead past)' (2008: 46). Here that reality is little more than the trace of a crucifix.

The Daisy Chain follows in the footsteps of earlier Irish cinema by deconstructing traditional ideals and reimagining the position of family, religion, gender and sexuality. It attempts to deessentialise the cinematic tropes of Ireland, and to explore the contradictions and complexities of Irish identity, its multiplicity rather than singularity, its past and its future. Yet, The Daisy
Chain could also be accused of reinforcing stereotypes of soft primitivism (in its allusions to changelings and simple country folk), as well as criticised for its possibly regressive representation of autism. And the representation of femininity as monstrous and murderous might well be read as a return to the idea of the feminine as abject. However, The Daisy Chain might also be read as a film which presents prejudiced positions in order to destroy them, in contrast to movies which are so desperate to be politically correct that they whitewash over the prevalence of real discrimination. This film outlines the prejudice faced by those who disturb cultural insularity. It considers the ease with which social hysteria is created both onscreen and off, as the sophisticated spectator is reduced to elemental beliefs and becomes fearful of what may in reality be just an unusual child.

Shrooms, Isolation, Seer and The Daisy Chain question the benefits of modernity, interrogate the history of Ireland and challenge elements of social politics and contemporary culture through mythology. In all of these films, the victim is also quite possibly the attacker, as illuminated in the final sequence of The Daisy Chain where the child is both nurturer and killer. Here, as in films on abused revenging women such as Hard Candy (Slade 2005), Kill Bill (Tarantino 2003) and The Brave One (Jordan 2007), characters coexist on the borderlands of humanity, abused and abusing, monstrous feminine and feminine ideal. But The Daisy Chain is more than a feminist polemic, it is an enquiry into the workings of the human mind and the society that produces. Like the best of its genre, The Daisy Chain refuses simple conclusions and terrifies through uncertainty and the fear of the unimaginable. As an investigation into the existential it is a complex achievement, and one of the most interesting horrors of Irish cinema.

Zélie Asava has lectured in Gender and Race in Cinema, French, American, Irish and World Cinemas at University College Dublin and Trinity College Dublin. She is the author of articles on the intersection between race, gender and sexuality in American, Irish and French cinema. In 2009 she completed her $\mathrm{PhD}$ on mixed-race representations in American and French cinema. 
The Daisy Chain (Irl, 2009)

Director: Aisling Walsh

Writer: Lauren Mackenzie

Principal Cast: Samantha Morton, Steven Mackintosh, Mhairi Anderson

Cinematographer: Simon Kossoff

Music: David Julyan

Producer: Graham Begg, Jamie Carmichael, Linda James, Tristan Lynch, Aoife O’Sullivan, Meinir Stoutt, Dominic Wright

\section{Works Cited}

Creed, Barbara. 1993. The Monstrous-Feminine: Film, Feminism, Psychoanalysis. Routledge.

Garner, Steve. 2007. Whiteness: An Introduction. Routledge.

McLoone, Martin. 2008. Film, Media and Popular Culture in Ireland. Dublin: Irish Academic Press.

Meaney, Gerardine. 2007. "Not Irish Enough? Masculinity and Ethnicity in The Wire and Rescue me", Postmodernism and Irish Popular Culture, ed. by Edited by Wanda Balzano, Anne Mulhall and Moynagh Sullivan. London: Palgrave Macmillan. 
Troubles Cinema: Five Minutes of Heaven (Oliver Hirschbiegel, 2009) \& Fifty Dead Men Walking (Kari Skogland, 2008)

Ruth Barton

Two very different films appeared in 2009 to remind us that Troubles cinema has not gone away. Canadian Kari Skogland, who works mainly in television, directed one, Fifty Dead Men Walking. The other was Five Minutes of Heaven, directed by Downfall (2004) director, Oliver Hirschbiegel. Both share the same producer, Eoin O'Callaghan, but little else. I mention Fifty Dead Men Walking more to dismiss it than to linger on it. An informer narrative, based on the eponymous memoir by Martin McGartland, the film is set in Belfast in the 1980s. McGartland (Jim Sturgess) is an innocent charmer and lad-about-town who is hired by the British Secret Service (headed by a lugubrious Ben Kingsley who works under the code name "Fergus") as an informer. Acting on what he believes to be proper principles, McGartland soon lands himself in deeper water than he could have anticipated and is eventually sold out to the IRA by the British. A last minute rescue sees him flee the site of his torture and set up anew in Canada. The title refers to the fifty men McGartland believes himself to have saved by informing, though in the end it seems that he will never be able to save himself. Shot in fastpaced contemporary thriller style, the film is marked by its determination to present the Troubles in as entertaining a manner as possible. Only when the drama slows towards the end is the viewer left in the uncomfortable position of having to reflect on the narrative construction or indeed to consider the moral message, if there is one. In the place of complexity come all the thrills of McGartland's possible detection, their reality-effect guaranteed by the knowledge that they are based on actual events. This in itself proved problematic for the film's makers when
McGartland threatened an injunction that would have prevented Fifty Dead Men Walking's gala screening from taking place at the Toronto Film Festival of April 2009. His argument was that the film did not represent his position accurately. In the end, a confidential agreement was reached between the producers and McGartland, and the screening went ahead. Subsequently, a number of journalists reported that McGartland had contacted them following their reviews to "correct" inaccuracies. Skogland herself told Michael Dwyer in The Irish Times that:

I liked the universality of the story because, whether it's happening in Ireland or Iraq or in an inner city, the notion of someone choosing to go against their community and potentially giving up their life and their future, or facing torture as retribution, was a very compelling story. That's what hooked me; the human drama behind it.

Others, notably Ronan Bennett in The Guardian, argued for the problematic nature of all informer narratives, particularly one that seeks to justify or glamourise informing (McGartland wrote to The Guardian "correcting” Bennett). Overall, Fifty Dead Men Walking is best defined as a project conceived with some naivety and almost complete indifference to historical accuracy, a criticism that will sound familiar to anyone who has studied Troubles cinema.

A more considered piece, Five Minutes of Heaven is concerned with exploring the issues surrounding reconciliation. The narrative focuses on two men, one, Alistair Little (Liam Neeson), a former Loyalist killer who has done time for the murder of a Catholic, Jim Griffin (Gerard Jordan), an act witnessed by Jim's younger

ISSN 1699-311X 
brother, Joe Griffin (James Nesbitt). In the spirit of reconciliation, a television company that makes One on One (a programme about "the man you could become" in the words of the researcher), plans to bring the two men face-toface for the first time since the assassination. Little is now a peace worker; Griffin is an emotional wreck, revisited by flashbacks of the murder and his mother's accusation that he could have prevented it. He is unable to respond adequately to his wife and two young daughters and his home life is fraught. Following Griffin's last minute refusal to appear in front of the cameras, Little seeks him out and the two face up to each other in a cathartic fistfight.

Reviewing Five Minutes of Heaven, the Hollywood Reporter critic commented perceptively that: "This highly emotional, very talky movie, which feels more like a play, seems best suited to television in the U.K., parts of Europe and South Africa, where people are coming to grips with the crimes of civil wars and genocidal atrocities." Yet, for all its postTroubles emphasis and exploration of the ambiguities of reconciliation, Five Minutes still rehearses many of the signifiers of conventional Troubles cinema. For instance, the opening sequences emphasise the commonalities shared by the killer and the victim, now played by Mark Davison and Gerard Jordan. Each is brought up in an old working class Lurgan house in a narrow street decorated by political murals; both families are watching the popular BBC Saturday evening show, Bruce Forsyth's The Generation Game, as one young man prepares to shoot the other; the victim's mother is the canteen lady at the apprenticeship of one of the Loyalist gang's members. In this community, ties are as strong as divisions. In common, too, with Troubles cinema narrative conventions, the killing is identified as senseless - Jim Griffin was about to leave the stonemason's yard where he worked to set up his own business anyway.

"Truth and reconciliation... I'm going for revenge", Joe Griffin promises himself in the mirror as he waits for his nemesis to arrive and the programme to start filming. A cut-away shows Alistair Little being driven along the coast to the stately home where the programme is being made, the magnificent house a symbol of the distance, literally, of peace and reconciliation from the streets. The edit underlines the philosophical message - each man is the mirror image of the other, each needs the other to complete himself. Griffin's "Five Minutes of Heaven" will be, he hopes, when he refuses reconciliation and knifes Little. In the end, however, he cannot bring himself to execute his plan.

The film has little sympathy for the kind of programme that is to bring the two men together; Griffin rails against the platitudes such television making reproduces, its voyeuristic nature, the excitement that its viewers will feel on seeing a real killer. Little's own introduction to camera seems rehearsed: "For me to talk about the man I have become, you need to know about the man I was ...”, a story so often told that it has lost its bite.

Just as The Quiet Man (John Ford 1952) sought redemption for its killer in a physical punch-up, so Five Minutes advocates the abandonment of words for a display of pure, unreconstructed male aggression. Throwing punches at each other is a primitive reconciliation, or catharsis, based on touch and pain, but it is, apparently, all there is. The fight sequence ends with both men falling through the upstairs window of the Griffins' old, abandoned home, and landing on the pavement below; they both lie there prone for a few seconds before raising themselves, reborn, from the ground. "I wanted to be someone; I wanted to walk into the bar a man, walk in ten foot tall and hear the applause from the only people who mattered to me then. And I heard it. And it was good," Little confesses to Griffin before exhorting the Catholic to forget him and to return to his wife and children. Still, Little, the Protestant, remains the rational thinker, Griffin, the Catholic, his volatile, emotional Other, even now unable to articulate his own experiences.

Of course, the real showdown is between two of Northern Ireland's most celebrated actors and this is what gives Five Minutes its edge. The ironies of the casting - Neeson is a Catholic, Nesbitt a Presbyterian - will have been lost on most audiences but must surely have informed the performances. Both men were born in Ballymena, both enjoy international reputations, 
although Neeson remains the most familiar face in Hollywood while Nesbitt is better known for his appearances on British television (notably in the long-running ITV comedy series, Cold Feet). Nesbitt has appeared more frequently in Northern Ireland dramas - The End of the World Man (Bill Miskelly, 1985), This is the Sea (Mary McGuckian, 1988), Resurrection Man (Marc Evans, 1998), The Most Fertile Man in Ireland (Dudi Appleton, 1999), Wild About Harry (Declan Lowney, 2000), Bloody Sunday (Paul Greengrass, 2002); for Neeson Five Minutes was a return home, both narratively, but also professionally, an opportunity perhaps to square up to the "local boy". Nothing in the performances suggests that there is any love lost between the two men, rather more that we are watching a display of competitive masculinity, a kind of gladiatorial spectacle.

The credits at the end of the television broadcast of Five Minutes thank the two men whose own stories provided the background to the semi-fictionalised events. It also supplied details of help lines for viewers affected by what they have seen, thus positioning the production itself within the parameters of the fictional programme on reconciliation it had so recently satirised. These ironies and the production's own unresolved ambivalences - the word or the fist ultimately reflect, rather more than reflecting on, the continued tensions surrounding reconciliation in Northern Ireland.

Ruth Barton is a lecturer in Film Studies at Trinity College Dublin and the author of Jim Sheridan Framing the Nation (2002), Irish National Cinema (2004), Acting Irish in Hollywood: From Fitzgerald to Farrell (2006) and a forthcoming biography of Heddy Lemarr. She is editor of Screening Irish America (2009) and co-editor (with Harvey O'Brien) of Keeping it Real: Irish Film and Television (2004). 


\section{“Looking at the Stars": TV3 adapts Lady Windermere's Fan}

\section{Liam Burke}

As any film student will tell you, in the last years of the $19^{\text {th }}$ century the technical innovations of Étienne-Jules Marey, George Eastman, Thomas Edison and many others produced a scientific curiosity without any definite application, the motion picture. Like all new media, the device was greeted with suspicion by the champions of established forms. Such misgivings were compounded by the innovation's earliest application, projecting novelties and actualités for the lower class audiences of music halls, vaudeville theatres and other venues of ill-repute. Before cinema's narrative potential could be fully realised, the form was already dismissed as disreputable by many. ${ }^{1}$ Thus, to achieve greater legitimacy, the newly discovered storytelling medium was aligned with respected forms and canonical texts, with early film-makers adapting heavily from literature. Using cherished texts to trellis the fledgling forms' climb to cultural legitimacy, the literary clout of Shakespeare, Dickens, Zola and others enabled film-makers to attract middle class audiences to its newly constructed nickelodeons.

This tactic of gaining cultural capital from adapting agreed "classics" is not confined to cinema, but is replicated throughout the history of the arts; as Marshall McLuhan remarked, "the 'content' of any medium is always another medium” (1964: 8). In 2009, the newest and most commercially driven of Ireland's national broadcasters, TV3 made a similar grasp at respectability, adapting Oscar Wilde's Lady Windermere's Fan for its first foray into feature length production. Belonging to Laura, a contemporary reworking of the revered playwright's first stage satire, was part of the

1. Desmond and Hawke note that, 'In the period between 1895 and 1903, cinema was not primarily a storytelling medium. Certainly there were some narrative films; however, until around 1904 early cinema saw storytelling as a subordinate task' (12). broadcaster's wider ambitions to rise above the mire of overseas imports and cheaply produced daytime shows for which it is known. In 2009 the changed ambitions of the oft-maligned station could be characterised by the play's most famous line, "we are all in the gutter, but some of us are looking at the stars".

TV3 began broadcasting in 1998, and as Ireland's first commercial broadcaster it has often been dismissed as the least reputable of the programmers, much to the annoyance of its creative personnel. For example, the station would not submit any programming for consideration to the 2009 Irish Film \& Television Awards as they had not won in the previous five years and they believed that the event was unfairly weighted in RTÉ's favour (Nolan 2009). However, this move smacked of sour grapes, as TV3 had few home productions during this time and could not expect to compete with the traditional broadcasters at ceremonies that recognised indigenous work.

Traditionally, the majority of TV3's programming has been internationally sourced, with primetimes schedules regularly packed with US dramas (Judging Amy, Buffy the Vampire Slayer), Australian sitcoms (Kath \& Kim) and UK reality television programmes (I'm $a$ Celebrity... Get Me Out of Here!, Love Island). Such is the extent of TV3's reliance on one-time parent company ITV's productions that the station was often found simultaneously broadcasting the schedules of the British channel, despite its availability in most Irish homes. Even today, long after ITV sold its share in TV3, the station continues to simulcast many ITV programmes (such as Coronation Street and The $X$ Factor). TV3's reliance on overseas productions has regularly found the network criticised for a lack of identity, with the Irish Independent noting in 2006 that "TV3 has never fully managed to develop a distinctive, clearly Irish identity” (Stacey). 
Traditionally, Irish productions on the station were confined to the daytime schedules with Ireland AM, a breakfast show, TV3's longestrunning production (with the exception of news and sports programming). However, in recent years the more firmly established station has begun making concerted efforts to distinguish itself in the broadcasting landscape. When appointed director of programming in 2007, Ben Frow a former commissioning editor for Channel 5 in the UK, said of the station, "I think we need to do more home produced [programmes] to give us a better sense of identity, give viewers what they really want, reflect TV3's values and help us be less reliant on acquisitions" (IFTN Broadcasters Spotlight - Ben Frow TV3). Soon enough, original Irish programming began creeping into the evening schedules with the introduction of a daily entertainment magazine show Xposé in 2007, and a version of the successful US series The Apprentice, with Irish candidates vying to work for businessman Bill Cullen. Furthermore, the late night current affairs programmes Tonight with Vincent Browne and Midweek, which began broadcasting in 2008 and 2009 respectively, continued the discussion of national topics into the late night schedules. Another, major turning point for the channel was the acquisition of the cable and satellite station Channel 6. In concert with the newly established TV3 Group, Channel 6 was renamed 3e in 2009. 3e took over broadcasting many of TV3's overseas entertainment programmes, freeing the channel to create Frow's promised new identity.

As part of this strategy, the channel made its first attempt at an original long format production with a TV movie for the 2009 Christmas schedules. Like many fledgling entertainments, the station ensured the production had built-in credibility by adapting an indisputable 'classic' for Belonging to Laura, a contemporary update of Oscar Wilde's Lady Windermere's Fan. The importance of Belonging to Laura to TV3 could not be mistaken. The network thoroughly promoted it through its entertainment programmes Xposé and Ireland AM, TV3's website claimed it was 'the most eagerly-awaited Irish drama of the year', and the station even considered legal action against RTÉ when the broadcaster's Christmas edition of the television magazine, RTÉ Guide incorrectly listed the film in its schedules (McConnell). Furthermore, lest viewers doubt the film's literary pedigree, the source material was constantly reinforced with the "Based on Oscar Wilde's Lady Windermere's Fan” tagline appearing in each advertisement.

Wilde's play follows the mysterious Mrs Erlynne's attempts to break into late Victorian society. She is aided, although we do not know why, by Lord Windermere, provoking gossip from the puritanical upper crust and sending Windermere's wife to seek out another man, Lord Darlington. Some typically Wilde-like misunderstandings occur before Mrs Erlynne (revealed to be Lady Windermere's mother) sacrifices her fledgling reputation to save her daughter's. One could hardly think of a more appropriate source material for TV3's strive for credibility. Much like Wilde's scarlet woman, TV3's youthful indiscretions have seen the station excluded from the upper echelons that the more reputable broadcasters freely enjoy, but with Wilde's literary clout the broadcaster may now finally "get into this damned thing called Society".

Of course, Belonging to Laura is not the first adaptation of Wilde's play. In 1916, when British films borrowed heavily from theatre, Fred Paul directed West End actors in a silent version that was largely faithful to the source, with the exception of revealing Mrs Erlynne's background in the first scene, thereby making her a sympathetic protagonist rather than an uncertain presence. Otto Preminger adapted the play for the 1949 version The Fan starring George Sanders as Lord Darlington. Preminger added scenes of an elderly Mrs. Erlynne reminiscing in Blitz-hit London to frame the Victorian setting, which otherwise may have rankled film-goers still relying on ration books. This version leans more heavily on the play's melodramatic underpinnings than its social satire, but is effective in opening up Wilde's drawing room drama to fit a cinematic proscenium. More recently, Helen Hunt and Scarlett Johansson starred in a version that relocated the setting to Italy's Amalfi Coast in the 1930s. Adopting the play's subtitle, A Good Woman (Mike Barker 2004) stretched fidelity by interpolating Wilde witticism from outside the source. Although the younger cast flounder, Hunt and Tom Wilkinson (as Lord Augustus) achieve 
a quick-fire repartee, absent in other adaptations.

Belonging to Laura marks the greatest departure from the source material of any previous adaptation. The film, co-produced with Samson Films (Once), resituates the narrative to modern day Dublin. Lady Windermere, now Laura Wilde (lest there be any confusion of the author), is due to marry Tiernan Fitzpatrick at her father's palatial South Dublin home, when rumours of her fiancé's stag-night transgression begin to emerge. Although Belonging to Laura faces its own charges of infidelity, director Karl Golden dismisses any misplaced reverence, stating ahead of the broadcast, "My attitude is that if Oscar Wilde was looking down on us he'd be encouraging us to fuck with his drama... the last thing I wanted to do with this was to have a theatrical style film” (Moon 2009).

Many of the film's amendments are appropriate. As outlined in the preface, the adaptation is set in the "The Present" rather than in 1892, when it was first performed at London's St James Theatre. Thus a modernisation is fitting for a play and playwright celebrated for satirising contemporary mores. In keeping with this present day setting, Belonging to Laura includes some clever variations on the source: The puritanical upper crust are gone, replaced by pseudo-bohemian Dublin loafers, who only eat organic appetisers and live off their parents' money - in Laura's case a tax-exile father; the titular fan is refashioned to an equally "essential" accessory, a designer bag (appropriate for a generation that queued in their thousands for a voguish carrier bag) ${ }^{2}$ and Ireland's multiculturalism is reflected with Indian-themed marquees, Korean chefs and a Polish wedding band. There's even an oh-so-modern scene where the priest offers relationship advice to the couple's lovelorn gay friend, "swallow your pride, pick up the phone".

Furthermore, in keeping with TV3's newly discovered nationalism, the characters (in the play named after British places) have each been given the type of Oirish monikers (Oisín, Kiernan, Tiernan etc.) typically only found in

2. In 2007 the sale of the limited edition 'I'm Not A Plastic Bag’ carrier bag, popularised by eco-conscious celebrities such as Keira Knightly, saw queues of thousands lining up outside Ireland's Brown Thomas stores (O’Brien). a Fáilte Ireland commercial. Such is the extent of the film's repatriation of Wilde's play that one of the wedding party guests suggests a culinary geographical faux pas is "offensive, like calling us British" - ironic for a station that viewers regularly confuse with its UK alternate.

Golden had promised to remove the play from the limits of its theatrical origins, and indeed the adaptation does feel like a film - a Richard Curtis film (Notting Hill, Love Actually). Owing much to the British director, many of the characters seem to have been picked up from Working Title's cutting room floor. From the attractive leads (the willowy Christina Carty and beefy Brendan McCormack), to the kooky inlaws and one-dimensional best friends (the fiery BFF, back-stabbing best man, the camp photographer etc.), each conform to established rom-com traditions. The characters may be Four Weddings and a Funeral, but the aesthetic is more Rachel Getting Married. The use of hand-held photography, solemn close-ups and shotsframed within doorways all strive for a voyeuristic cinéma vérité, but these stylistic flourishes are at odds with the film's inevitable descent into soapiness.

All adaptations of Lady Windermere's Fan have struggled to balance the play's delicate mix of satire and melodrama, with the scales generally tipping toward the latter - and Belonging to Laura is no exception. TV3's publicity for the film promised a "hilariously witty remake of Oscar Wilde's classic play” (On the Town: Belonging to Laura), yet these moments never fully materialise. Although there are some attempts at broad comedy and a few neat observations - the adaptation's Lord Darlington has a D4 address with views of the Poolbeg chimneys - there is no sustained satire, with any sparks snuffed out beneath the weight of the maudlin interpretation. This is a disappointment, as the film hints at some prime opportunities to ridicule a group of people for whom D4 is not a postal code but a way of life.

It should be noted that the film-makers display considerable restraint in not using many of the play's oft-quoted lines. However, one would have to question the decision to have the few direct quotes come from the film's only homosexual character - an over-the-top caricature that stops to admire the flowers and pines after the groom - presumably the film-makers thought only a 
dandified character was capable of delivering Wilde's witticisms in a contemporary context.

The greatest sacrifice to the adaptation's romcom approach is the play's dominant presence, Mrs Erlynne. In more faithful adaptations, the puritanical Lady Windermere can come across as foolishly naïve - believing scandal rather than her husband and running off to Lord Darlington's home at the slightest suggestion of marital impropriety. To redress the balance the film attempts to make Laura more sympathetic and justify her actions. Resultantly, Tiernan is uncertain as to whether he cheated on his fiancée after an alcohol-induced black-out (he didn't) and Mrs Erlynne (Tatiana Ouliankina), now Sasha - a Prada-wearing Russian "international sex Goddess"- is content to let the couple (and the audience) believe the lie. This makes Sasha's reveal as Laura's mother feel more like a plot contrivance from actress Ouliankina's former soap Fair City, and by the time the character makes her self-sacrificing gesture, traditionally the play's most emotive moment, the audience is firmly in Carrigstown. This is not to diminish the performers, Ouliankina certainly has the look of a formidable Mrs Erlynne and newcomer Carty shows some genuine promise, but despite the film starting well and including some clever interpretations, it ultimately is too unsure of itself and its source material to win Lady Windermere many new fans.

In a particularly quotable scene from Lady Windermere's Fan one of Lord Darlington's reprobates, Cecil opines, "a sentimentalist... is a man who sees an absurd value in everything, and doesn't know the market price of any single thing”. One could certainly not accuse TV3 of sentimentality, recognising the value the credibility of a theatrical adaptation might bring; the broadcaster refashioned Wilde's original play into an accessory befitting a station on the rise. Although this interpretation may not have enabled Lady Windermere to pick up any new fans, TV3 certainly did with the film nominated alongside productions from BBC, TG4 and RTÉ in the Best Single Drama category at the onceimpenetrable Irish Film and Television Awards. Although, the film failed to convert the nomination into a win, the adaptation had served its function, as Belonging to Laura is less a film than a declaration of intent: TV3 is a legitimate broadcaster and now has the accessories to prove it.

\section{Works Cited}

“Belonging to Laura - TV3”. 2010. Catch-up TV, Entertainment, News, Sport, Soaps and all your favourite Irish and International shows from TV3. Web. 17 Feb. <http://www.tv3.ie/shows.php?request=belongingtolaura>.

Desmond, John M., and Peter Hawkes. 2006. Adaptation: Studying Film and Literature. New York: McGraw-Hill.

“Doughty Hanson acquires TV3.” 2006. Vc-jobs.com. Adfero Ltd., 24 Mar. [accessed 15 Feb. 2010]

http://www.vcjobs.com/newsDetail.faces?newsArticleId=124\&newTitle=Doughty+Hanson+acquires+TV3

“IFTN BROADCASTERS SPOTLIGHT - Ben Frow TV3 | The Irish Film \& Television Network.” 2007. IFTN, 14 Sept. [accessed 18 Feb. 2010]

<http://www.iftn.ie/digital/digitaltv/?act1=record\&only=1\&aid=73\&rid=4280646\&tpl=archnews\&force=1>.

McConnell, Daniel. 2009. “RTE faces lawsuit from TV3 over listings error.” Irish Independent, 20 Dec.

McLuhan, Marshall. 1964. Understanding Media: The extensions of man. London: Routledge.

Moon, Aileen. 2009. “Karl Golden Talks? Belonging to Laura?” IFTN. Irish Film and Television Network, 17 Dec. [accessed 16 Feb. 2010]

$<$ http://www.iftn.ie/crew/crewnews/?act1=record\&only=1\&aid=73\&rid=4282776\&tpl=archnews\&force=1 >

Nolan, Lorna. 2009. “TV3 will shun IFTA Award coverage.” The Evening Herald [Dublin], 8 Jan.

O’Brien, Jason. 2007. “I’m not a plastic bag, I'm a fashion phenomenon.” Irish Independent ,12 July.

“On the Town: Belonging to Laura - TV3.” Catch-up TV, Entertainment, News, Sport, Soaps and all your favourite Irish and International shows from TV3. 2010.

<http://www.tv3.ie/article.php?article_id=28659\&locID=1.65.68.273.\&pagename=xpos. [accessed 17 Feb 2010]

Stacey, Pat. 2006. “TV3: lots of Heartbeat, but there’s little pulse.” Irish Independent, 21 Jan.

Liam Burke is a PhD candidate and IRCHSS Scholar at the Huston School of Film \& Digital Media, NUI Galway 
Masks and Faces: Identities (Vittoria Colonna, 2008)

Denis Condon

While the absence of a live-action feature from the Dublin Critics' Circle "Irish films of 2009"1 was a telling comment on the quality of Irish fiction features that were released last year, the situation was considerably better for feature documentaries; notably Joel Conroy's Waveriders and Alan Gilsenan's The Yellow Bittern: The Life and Times of Liam Clancy (both of which are discussed elsewhere in this year's review). Alongside these, a number of other documentaries did well on the international festival circuit: Ken Wardrop's His and Hers receiving Sundance's World Cinema Cinematography Award for documentary and Ross McDonnell and Carter Gunn's Colony winning the First Appearance Award at the International Documentary Film Festival in Amsterdam.

Vittoria Colonna's Identities should be counted among the year's considerable documentary achievements. The film offers insightful glimpses into the lives of five transgender people living in Ireland. A sequence of the film focusing on one of these individuals received the Irish Council for Civil Liberties (ICCL) Human Rights Film Award in June, and the full film won the documentary award at the Gaze Film Festival in Dublin in August.

The film begins with an epigraph from Oscar Wilde's The Critic as Artist: "Man is least himself when he talks in his own person. Give him a mask and he will tell you the truth." Although quoting a queer Irish author discussing the revelatory power of artifice seems particularly appropriate to a film that will explore sexual and gender identity partly through

1. http://dublinfilmcriticscircle.weebly.com/2009.html performance, it is striking that as soon as the film begins, those uses of the generic "man" and the pronouns "he" and "him" are put into radical question. Because documentary conventionally operates not at the level of the generic but of the specific, Wilde's “man” is subsequently represented by five individuals living in Ireland in 2008, whose life stories suggest the contingency of such terms. In five separate sequences of approximately fifteen-minute each, these social actors engage in performance and allow the camera to observe aspects of their lives in order to reflect on the importance to them of sexuality and gender identity.

Each sequence consists of a performance piece shot in colour and a longer observational segment shot in black and white as the social actor engages in everyday activities. Because three of the social actors are also stage actors who perform drag acts, the performance pieces work best in these sequences, which are the first three we see. So, in the first sequence, Fabio Ferri poses alluringly framed against glass shards and crystal chandeliers as well as later in his drag-queen persona of Sibyl Vane (another Wilde reference or is it Nabokov?). In an chiaroscuro-lit pool, Leonid Dale Belino dances with goldfish bowls, before discussing the surgical procedures $\mathrm{s} /$ he has undergone to become a "pre-op" transsexual and his/her role in the introduction of Filipino ladyboy culture to Dublin in the form of a ladyboy beauty pageant. Shani Williams performs a rockabilly song in her personae of Slick O' and Sade O'Saphhic and then explores the drag-king world with her partner and drag-king friends.

In both performances and observational segments, these sequences are largely exhibition-

ISSN 1699-311X 
istic and celebratory. For these practiced performers, the format works well, and a strong sense of collaboration between filmmaker and social actors is apparent. The sense of almost seamless progression from artistic selfpresentation into observational segment is explicit in Ferri's sequence, in which the camera follows him from his performance set to the dressing room and he begins speaking to camera. Filmmaker and social actors worked on together on these performances, helping to build relationships of trust that allow for the intimacy of the observational segments. Colonna succeeds in establishing close bonds with the film's social actors, but hers remains an outsider's view. She does not appear directly on camera, but she is an interrogatory presence who occasionally asks questions and the social actors several times address comments back to her. She is most present in the film when Williams, dragging up as Slick, displays her "pack" - the prosthetic penis that forms part of the costume of the drag king - and invites Colonna to feel it in place, which she obligingly reaches out her hand from behind the camera to do. Although the film is not voyeuristic in its focus on the naked bodies of the social actors or details of surgical procedures some of them have undergone, it does show the performers moulding their bodies into desired shapes. Displaying his own upper body, Belino explains that ladyboys remain as pre-op transsexuals, choosing to have hormone therapy, breast implants and other procedures to make their bodies appear female but retaining their male genitalia.

Given how recently (1993) homosexuality has been decriminalized in Ireland, it is surprising the degree to which the foreign-born transgenders present the country as a place of sexual freedom. For Ferri - a gay Italian crossdresser - and Belino - a Filipino transsexual Ireland is the place where they have been able to most fully develop their identities. Ferri discusses the difficulties of coming out and discloses how in his youth he was raped by a man. That Ireland has become a refuge for him, however, need not reflect credit for great shifts in Irish attitudes or legislation. Like Irish people who escaped sexual repression in Ireland to discover a place for self-fashioning abroad, there is the sense that Ireland is that anonymous somewhere - anywhere - else that a person with a sexual preference or gender identity other than that of the majority needs to be themselves. Indeed, although the film shows that Ireland has become a destination for people of many ethnic affiliations and a variety of gender identities, this does not mean that the Irish have become a people especially tolerant of gender difference. This is made clear not only when, for instance, Williams and other drag kings comment on the possibility of being beaten up for looking different but also and more comprehensively in the stories told by the two Irish-born social actors - Lee Stella and Sean/Crystal Lesley.

Indeed, the Irish sequences do not manifest the largely celebratory tone of the preceding ones. The close consultation required between filmmaker and social actor by the performance pieces is most under strain in these final two sequences featuring Stella - a female to male transsexual who works as a taxi driver - and Lesley - a cross-dresser and author - neither of whom is used to performing his gender in the same explicit way as Ferri, Belino and Williams are. Stella's sequence begins with him stripped to the waist training at night with a punching bag in a forest, the sense of performance heightened by setting, music and editing. Lesley's sequence ends not with his performance but with his absence from the image track, on which the camera slowly zooms in on an empty chair, while on the soundtrack, he reads some of his own writings. Religious pronouncements on gender identity seems to preoccupy both Lesley - who mentions his correspondence with the Pope on transvestism - and Stella, who begins the observational segment of his sequence by asserting that “God doesn't make mistakes" and that his birth as a woman had been necessary so that he could give life to his daughter, Siobhan.

While religion is a definitive presence in Lesley's sequence, Stella's focuses not on God but on his relationship with his daughter. Siobhan's participation and her unequivocal support for her mother's decision to change gender lend this sequence a particular autonomous coherence. It is not surprising that the filmmakers chose this sequence to compete for the ICCL prize (called My Identity, this film 
is viewable at http://vimeo.com/4849073). Nevertheless, it is also crucial to the impact of the full film as an exploration of gender identity in Ireland. Although the earlier sequences do locate themselves in Ireland - showing Belino working as a nurse or Williams's Irish drag-king friends, for example - their focus on foreignborn individuals could be construed as suggesting that transgender identity is in some sense a recently imported phenomenon and that it is typically expressed in exuberant performance. These impressions are dispelled by Stella's low-key performance of the ordinary Dublin taxi driver. This is seen in his declaration that he does not tolerate abuse from those who travel in his taxi, and Siobhan's discussion of her courageous stand against school bullies who taunted her over her mother's gender dysphoria. Stella does contribute artistic performance, not only during his opening boxing routine but also by playing guitar and singing songs that he has composed both for women he has desired and for Siobhan. However, the testosterone therapy that has helped him to escape from his hated female body and to look like the man he wishes to be has caused his voice to drop, and he regrets that he "can't sing for nuts now.” Nevertheless, with a close and loving relationship with Siobhan, the film suggests that he has overcome the worst of the mental and physical anguish and is, like Ferri, Belino and Williams, content with his gender identity. The same cannot be said for Lesley, whose blatant vulnerabilities make his sequence the most uncomfortable viewing. Although the film's modular structure seems to confine the social actors to their own separate spheres - acknowledging perhaps the actual separation of differently gendered individuals screenings of it have provided an occasion to think across these lines. At GAZE (Dublin's Lesbian \& Gay Film Festival), for example, the five social actors were warmly received when they appeared together on a question-and-answer panel.

Denis Condon lectures on cinema at the School of English, Media and Theatre Studies, NUI Maynooth, where his research and teaching interests include Irish cinema, early cinema and popular culture, Hollywood and documentary. His book Early Irish Cinema, 1895-1921 (Irish Academic Press) appeared in 2008. 


\title{
Being Digital - Irish cinema and digital production
}

\author{
Roddy Flynn
}

Within Europe (for which read the European Commission), new technology has long been identified, if admittedly in a somewhat vague fashion, as a potential means of reversing a century of US dominance of global screens. From its inception as a pilot project in 1987, the European Union's MEDIA programme has devoted a significant proportion of its funding to training media professionals in the use of new media production (i.e. digital) technologies to enable them to leapfrog over their US counterparts. It remains a key focus of the current Media 2007 programme which stresses the importance of supporting projects which aid European audiovisual professionals in "adapting their technical skills to digital technologies".

To its credit the EU has also recognised the need to address structural deficiences in European film-making which are less amenable to a "technological fix". However, there remains a remarkable faith in the power of technology to "solve" the problem of European cinema. One study on Spanish cinema published in Convergence identified digital technologies as a universal panacea for that industry:

Digital technologies offer the opportunity to modernise the industry, bringing with it financial savings and easier distribution, which in turn offer the possibility of not only increasing revenues, but also widening the reach of Spanish cinema. ${ }^{2}$

Though somewhat less breathless in its identification of the potential of digital media, Screen Training Ireland has also long been

1. http://europa.eu/legislation_summaries/audiovisual _and_media/l24224a_en.htm. Accessed 4 March 2010.

2. Kogen, Lauren. 2005. “The Spanish Film Industry: New Technologies, New Opportunities” Convergence, Vol 11, No 1, pp 68-86. convinced of the critical need for investment in digital training. When the national training body commissioned McIver Consulting in 2000 to report on the future training needs of the industry, the resulting document repeatedly stressed the importance of digital media, going so far as to recommend that Digital Media Sector Training be treated as a stand-alone strand in FAS's operations and recommended devoting a third of all screen-training expenditure to the area:

FÁS/Screen Training Ireland should undertake a new initiative to provide the business, creative and technical training that individuals and companies in the film, television and animation sectors need to take advantage of opportunities available in new markets for digital media. (emphasis in original). ${ }^{3}$

Although the opportunities deriving from the exploitation of digital technologies identified by these institutions relate to digital distribution and exhibition as well as production, it is the manner in which Irish film-makers have adopted digital effects/computer generated imagery which prompts this contribution to this year's review.

In theory, this discussion could have begun several years ago, most notably with the completion of the short film Prey Alone (of which more anon) in 2004. However, since then it has become obvious that there is a cluster of Irish film-makers - James Mather, Stephen St. Ledger, Ruairi Robinson and Nick Ryan - who are deploying CGI in a consistent pattern and with apparently similar objectives. Between them, they have produced and released five or six

3. McIver Report (2000), http://www.screentrain ingireland.ie/uploads/McIver.pdf. Accessed 4 March 2010, p. 7.

ISSN 1699-311X 
digital effects-laden short films since 2004 including Prey Alone (2004), Silent City (2006), A Lonely Sky (2006), The German (2008) and Bad Robot (2010). And, appropriately given their digital nature, most are available on Youtube in HD format.

Although all the individuals above have been working in aspects of film and commercials production since the mid-1990s, the founding text of the "movement" is unquestionably the Film Board supported Prey Alone. Anyone who has seen it in the context of a screening of a series of Irish shorts must have been startled by it: the narrative follows an unnamed figure pursued by shadowy elements of the US government, but who persistently evades capture. But though toying with a combination of blockbuster film/computer games conventions, the story is of secondary importance to the stunning visuals. The film is constructed around a set-piece chase sequence where a pair of fighter jets pursue a high performance auto along on a dark urban highway and then, in a physicsdefying turn, into an underground tunnel. The mise-en-scène draws from a variety of influences including Frank Miller's Sin City comics, ID Games Doom and Quake series and The Matrix trilogy, even down to exclusive use of American accents by the exclusively Irish cast.

By coincidence, James Mather was the cinematographer on the 2006 short A Lonely Sky directed by Nick Ryan, who usually works with Zanita Films as a commercials director. Written as an (unsuccessful) entry for the 2002 round of the Film Board's now defunct Short Cuts scheme, A Lonely Sky feels like a fantasy prequel to Philip Kaufman's take on The Right Stuff. Set in 1947, the film is set in a ramshackle bar where test pilots from a nearby airbase (Edwards?) debate whether breaking the sound barrier is possible, watched by an older, silent observer. The young America pilots are all played by Irish actors (including The Wind That Shakes the Barley's Padraic Delaney), although - in a nod to the fantasy genre - the older man is played by Keir Dullea from 2001: A Space Odyessy (an opportunistic piece of casting exploiting Dullea's 2005 performances in Red Kettle Theatre's production of Ira Levin's “Deathtrap” on stages around Ireland). Once again, however, the real star of the movie of the short is the effects Ryan has speculated that the Film Board's was reluctant to fund the film because it couldn't be done within the confines of a Short Cuts budget. His solution was to generate whole swathes of the film through digital effects: there are 80 effects shots in the 10 minute film, 60 of which are entirely computer-generated. So we watch a film which features extensive sequences of B29s, the Bell X-1 and a Lockheed P-80 shot against what appears to be the Mojave Desert, knowing that it was entirely created in Ireland.

Namechecked for thanks on A Lonely Sky is Ruairi Robinson, an NCAD graduate, who may be familiar to some as director of the 2004 Oscar-nominated animated short Fifty Per Cent Grey (although inevitably, he mainly makes commercials) On his witty website, Robinson bemoans the fact that the critical kudos which followed "Grey" did not lead to any significant professional interest in him as a potential feature director. Undeterred he wrote The Leveller, which emerged in 2006 as the Nick Ryan produced-short Silent City. And - guess what? Silent City is another CGI-reliant narrative, following three soldiers (Cillian Murphy, Don Wycherley and Garvan McGrath) on patrol across a geographically unspecific but postapocalyptic landscape straight out of The Terminator quadrology.

At a visual level these films constitute a highly impressive body of work. The aesthetic selfconsciously echoes the hyper-reality of CGIdependent Hollywood blockbusters from Titanic (1997) through to the Star Wars prequels. And the production values appear to confirm the faith of the MEDIA programmes in the potential of digital technology to allow film-makers working with European-scale budgets to match their financially better-endowed Hollywood counterparts. In truth, the Irish films don't always quite match Hollywood levels of hyper-verisimilitude: the aircraft in A Lonely Sky are a little too perfect, too clean whilst the pre-credits sequence from Silent City feels more like a computer game, cut-scene than a piece of cinema. But the "wow" factor is still there. And in point of fact, CGI is most successfully deployed in these films when recourse to it is not obvious. Aircraft flying through a tunnel screams "effect" but a distant 
city landscape on fire achieves greater verisimilitude.

But though the use of CGI permits the directors to create environments which completely disguise any associations with an Irish setting (going so far in Prey Alone as to opt for a virtual world), it remains the case that the presence of like Don Wycherley, Ger Casey and Padraic Delaney in the context of these filmic worlds is not merely unsettling for an Irish audience: it's positively disruptive, akin to the jolt experienced when Apres Match's Risteard Cooper suddenly popped up as a Gotham police captain in Batman Begins (2005) (along with a phalanx of other faces previously seen on Fair City).

Over the past decade or so there have been a number of Irish shorts which have paid homage to Hollywood genres (without resorting to CGI). Coolockland (2000), Eireville (2002), and Nun More Deadly (2005) almost constitute a subgenre in themselves, playing on audience familiarity with the conventions of film noir even whilst subverting them by transferring their narratives and characters to an Irish setting. However these films maintain a distance from their subject, adopting an ironic, if affectionate, stance towards film noir.

The same is not true of the CGI-ed work described above. These are not films commenting on the manner in which digital effects are deployed in Hollywood. Instead they unashamedly internalize the conventions of contemporary blockbuster film-making emphasis on spectacle, de-emphasising (though not abandoning) narrative - to produce films which do not pay tribute to mainstream US cinema but actually seek to become such cinema. This is arguably true even of Nick Ryan's more recent production The German which did the rounds of international festivals in 2009. Even if apparently set in (or more accurately over) England during the Battle of Britain, the CGI-ed Spitfire/Messerschimdt dogfight which constitutes its centrepiece recalls nothing so much as Michael Bay's depiction of the attack at the centre of his 2001 film Pearl Harbour. And even if some of the these films prominently feature an Irish cast (although this is not true of either The German of Bad Robot), the film- makers have clearly made a conscious decision to denude the films of any other cultural signifiers that would denote Irishness. Certainly the - generally enthusiastic - comments about the films online convey no sense that a Youtube audience identifies these films as Irish.

The question is whether any of this matters? Is there really any moral imperative for Irish creative artists with access to such digital toys to use them to make a contribution to a national cinema, especially given such texts unquestionably do deliver such visceral pleasures in spades? (Furthermore, it's not like some of them haven't already made considerable contributions to the national cinema "project": James Mather is a noted cinematographer, who worked on a number of Irish shorts in the 1990s, before moving onto a number of high profile film and television jobs, including Adam and Paul, Prosperity and Single-Handed.) Nonetheless, consider Paul Willemen's 2004 article, "Inflating the Narrator: Digital Hype and Allegorical Indexicality", in which he launched an assault against the manner in which digital effects technology was deployed by mainstream Hollywood productions. Citing the example of "bullet time" in The Matrix, he argues that the use of digital effects technology deliberately reverses realist cinema's impulse to disguise the existence of an author/director and instead draws attention to the creator's role in constructing not merely the narrative but the entire mise-en-scène of the film:

its inclusion in a narrative environment thereby also flips the narration into a discursive form that stresses the authority, even the authoritarian control of the narrator as the explicitly designated controller of "the seen" (Willemen 2004: 11).

For Willemen, digital effects technology is applied in this way as a means of differentiating Hollywood's product from that of other world cinemas by stressing its superior production values thus proclaiming "the power and wealth invested in the production resources themselves."

The falling cost of the underlying technologies even in the six years since Willemen's paper was published undermines that argument somewhat. A recurring trope in the online discussions of their work by these Irish directors of CGI-ed 
material is a stress on how little finance they had available to them and thus how much of the work they did themselves. In other words, they're demonstrating how much they can achieve with such limited financial resources. Indeed such comments coyly imply "imagine what I could do with a 'real' budget behind me."

And in this respect, another of Willemen's points has, if anything, taken on greater significance since 2004. Willemen notes that the use of such digital effects

invites us to pay attention to the powers and expensive technology gadgetry at the disposal of the speaker rather than to the stuff that it being narrated... what is being narrated at the time when the device is used is quite simply an ode to the apparently absolute powers of the discourse programmer (Willemen 2004: 11).

Applying this perspective to the Irish films under discussion clarifies their function: they are calling cards, stand-alone show reels, a point made overt by the fact that several of them Silent City and A Lonely Sky - are accompanied on youtube by "Making of" featurettes which dwell at length on the digital production process. Commenting on Silent City, Robinson notes that it was

a fantastic testbed for me to gear up techwise, and skillwise for anything almost anything that work throws me in the future. Basically I'm set up to shoot/edit and complete a feature film in high def now, without having to rely too much on anyone else. $^{4}$

In other words, Ruairi Robinson is open for business.

The notion that Irish short films primarily operate as calling cards is far from a new one: as far back as 1968, the Film Industry Committee Report noted that the commercial market for shorts was rapidly evaporating. The same report nonetheless recommended supporting short films as a means of allowing neophyte film-makers to learn their craft on the job. That same logic has clearly informed the decision by successive Irish film boards to put so many resources behind a whole smorgasboard of short film support schemes.

4. http://www.ruairirobinson.com/main.htm Accessed 7 March 2010
One could lament this narrow focus on shorts as stepping stones to features and point to a different tradition on the continent where established feature directors still occasionally return to the short form because of its intrinsic appeal. Tom Twyker, Patrice Leconte and Lars Von Trier (all of whom feature on DVDs which form part of the "Cinema 16" series) hardly need to establish their directorial chops at this stage in their respective careers. Nonetheless it appears to be the case in Ireland that short film production is a kind of rite of passage that must be completed before getting onto the real business of making features.

This prompts the question, however, as to what the CGI-ed shorts discussed above are stepping stones towards? There is no guarantee that the production of even a well-received Irish short will lead/trap a director into moving on to Irish feature. Six Shooter may have led Martin McDonagh onto In Bruges but John Moore's next fiction work after He Shoots, He Scores (1995) was Behind Enemy Lines (2001) and there's little evidence in Moore's subsequent output to suggest he hankers to return to make an Irish study. However, if calling card shorts are best understood as demonstrations of ability to operate at bigger budgets, exactly what kind of abilities do films like Prey Alone, Silent City or A Lonely Sky suggest? It is not obvious that these films point to a capacity (or even desire) to construct locally specific narratives.

For his part Robinson is refreshingly upfront about this saying of the Film Board-supported Silent City:

This is the film that finally got me an agent in Hollywood, where an Oscar nomination failed, and hopefully might help me secure one of those "career" things I keep hearing people talking about (http://www.ruairirobinson.com/main.htm).

In fact, in Robinson's case, Silent City not merely won him an agent but in March 2009, the blogosphere was awash with rumours that he was attached to direct a live action version of Katsuhiro Otomo's Akira for Warner Brothers.

Even if the Akira project appears to be on the shelf for now, others in the group appear to be further down the line to a first feature. In February 
2010, it was announced that Mather and were working with French producer/director Luc "The Fifth Element" Besson, on the development of Section 8, an English-language, feature-length, sci-fi spectacular about an escape from a futuristic prison located in Earth orbit.

All this suggests that the kind of thinking digital technology would constitute a great leap forward for European cinema - which has informed EU support of digital media training may have been a little naïve. After all, it was never likely to be the case that Hollywood would simply ignore the potential raised by digital technologies: instead companies like Industrial Light and Magic and Lightstorm have been the main drivers of cutting edge research and development into digital production technologies. In practice then, EU and Irish training in the use of such technologies has, at best, merely allowed our film-makers to keep up. And, ironically, Hollywood itself is often the direct beneficiary of such support, as the rags to riches of Ballyfermot Senior College animation alumnus Richard “Avatar” Baneham, illustrates.

In any case, at a local level, the focus on the importance of investing in digital skills, tended to stress the needs high-end digital animation demands of commercial production rather than those of the feature production sector. Postproduction houses like Windmill Lane and Screenscene have always been at the forefront of investment in leading edge production technologies, responding to the demands of ad agencies for material that will stand out from avalanche of marketing material that constitutes the background noise of contemporary Irish society. CGI has been one way of achieving this.

And all of the film-makers discussed above cut their teeth in the day job: advertising. But, ironically, it is the compromised, commercial world of advertising that one can see some of the best examples of how CGI might be applied to produce material specifically engaged with Irish culture. Even if you haven't seen James Mather's work on Adam and Paul or his collaboration with Stephen St. Ledger on Prey Alone, you've almost certainly seen examples of their commercials work for H2 Films. One of my favourite ad campaigns in recent years was that series commissioned for Amstel lager where four Irish blokes variously discover America, lay siege to Troy and build an Ark. Remember the casual call to a despairing Columbus? "Chris? Land over there.” That's arguably Mather and St. Ledger's most locally-engaged work, appropriate (nay essential) for an international brand seeking access to a specific market. For Paul Willemen, a reliance on digital effects is virtually incompatible with national cinema. He characterises Hollywood cinema since the 1980s as increasingly focused on the action cinema genre, and creating "a better targeted and more frenetically calibrated cinema of attractions" (Willemen 2004: 14). For Willemen "digital gadgetry .... came along to buttress and further speed up this dynamic.” By contrast national cinemas ("regions that find it difficult to compete with Hollywood") have stressed cinema's indexical qualities, exploiting cinema's "ability to allow meaning to proliferate and resonate" as means of interrogating reality (rather than supplanting it as occurs in, say Jurassic Park, The Matrix or Avatar). But, contra Willemen, the CGI-ed Amstel ads are almost entirely indexical - their images connected to ideas which are not overtly referred to. Compromised though it may be it does suggest that there's nothing inherent in digital technology which prevents it from being used to contribute to national cinema.

Dr Roddy Flynn teaches in the School of Communications, Dublin City University. He is co-author (with Pat Brereton) of Historical Dictionary of Irish Cinema (Scarecrow Press, 2007). 
The Yellow Bittern (Alan Gilsenan, 2009)

\section{Robert Furze}

As a documentary, The Yellow Bittern, subtitled The Life and Times of Liam Clancy, navigates the territory between the empirically researched and tantalisingly lyrical; as interviews, archived footage and journeys into places from the past attempt to recreate the folk singer's history, while certain details of the history itself remain curiously unexamined.

The facts, as vividly presented in the documentary, are presented more-or-less chronologically: Liam Clancy was born in Co. Tipperary in 1935. His family was poor. He became a huge admirer of literature, in particular poetry, at a very young age, an enthusiasm bolstered by a love of the oral tradition of Irish ballads the American blues tradition, as exemplified by the contemporary singer Josh White. He meets Diane Guggenheim, who finances his early singing career, but leaves his life after attempting suicide and being committed to an institution. Living in New York, Liam, his two brothers and childhood friend Tommy Makem form a folk quartet that is a success in both the United States and Ireland, performing in Carnegie Hall and on the Ed Sullivan Show. He meets and marries Kim. By the 1970s the group had run out of inspiration and money, a change in fortunes that culminates with Liam's alcoholism and a breakdown. The group disbands, returning for a reunion in 1984 . Finally, in a period from the early 1990s to 2007, Liam's brothers and Tommy Makem die, leaving Liam Clancy the last surviving member of the folk quartet. (But only briefly: Liam Clancy died in late 2009).

This history is presented in chapters, 'Boyhood' and 'Manhood', which could just as easily have been named (after William Blake)
'Innocence' and and 'Experience', as the first covers the years of wide-eyed simplicity destroyed by Guggenheim's attempted suicide (Clancy was 21 when this happened); the second the period of fame, addiction, decline, resurgence and eventually self-awareness and wisdom.

Structuring and re-telling Clancy's life in this way enables the film to indulge in some curious dualities and parallels between concepts of, for example, poverty and wealth, rural and urban, home and away. These are certainly underpinned by the genre distinctions of documentary and fiction noted above; but only insofar as they can confidently espouse the 'meanings' of national identity to a provisionally - transnational audience.

'Boyhood' places Clancy firmly in the Irish landscape. He recalls rambling shoeless throughout the wild country, a remembrance confirmed by contemporary footage of boys, some in bare feet, walking in a line along a rural track. The film stock, as with all the archive images of this period, is authentically poor: black and white footage flecked with dust and scratches. That these images are not of Clancy per se is hardly the point here; rather that they stand for Clancy's childhood, just as the younger, innocent Clancy himself stands for what McLoone terms "Irish primitivism", a "version of Ireland that presented the country as a potential Garden of Eden, populated by a simple, musically gifted, loquacious and happy ... peasantry” (2000: 36). This era of pastoral bliss is accented by Clancy's loving portrait of his parents' relationship, for which he reserves the adjective 'romantic'; and for the village where he grew up, which in the mid- to late1930s existed somewhere 'between the Middle Ages and the twentieth century'. 
Nonetheless the bucolic separateness of Co. Tipperary in this period is tinged with an awareness of a world elsewhere: Clancy's early career trajectory, to be a priest or an insurance man jars against his mental image of Tennyson's Ulysses sailing the seas, an idealised future intensified by his awareness of an America personified by the Blues and Diane Guggenheim.

Director Alan Gilsenan is undoubtedly aware of the contradictions inherent in this apparently simple equation. The young Clancy's 'America' is not merely antithetical to a rural Ireland of limited career prospects but is in some ways also its mirror. So amidst the nostalgia of Clancy's words and Gilsenan's found images, the film also manages to bring us (as Clancy observes) the 'real history' of the Irish peasantry, which in the art and language of Liam Clancy, is actualised through the tradition of the folk song. In these, the true desperation of rural life is told, and as Clancy sings a ballad of an ageing man afraid of illness and starvation, it becomes obvious that what attracted Clancy to the American Blues was as much its familiarity as its newness. The recreation of what appears to be a stereotype of Irishness in the cinematic imagination becomes, for the modern viewer, a more complex polysemy, which echoes the struggles of establishing a postmodern national identity as much as its revels in recapturing a lost innocence. As Brereton (2009: 29-31) writes on the "branding" of Irishness, "Ireland in the new millennium is encapsulated by a culture caught between its nationalist past, its European future and its more dominant American imagination" (30). Furthermore, Clancy's childhood becomes poignant in the post-hedonist, post-Celtic Tiger age: congruent, that is to more recent national anxieties over the possibilities of a loss of social status and the unwelcome return to a provincial past.

Clancy's boyhood innocence nonetheless comes to the surface as he meets the American heiress Diane Guggenheim (an ingenuousness exemplified by his unawareness of who the Guggenheims were). Diane's bankrolling of Clancy enables his emigration to New York recalling a particular brand of modernist patronage, even as the details of their relationship are left unclear. And as he describes his displacement to the cityscape, Clancy's words are accompanied by montages of archival material that expose the consumerist lifestyle into which he had been plunged. These images of young revellers with glasses of champagne and smoking cigarettes, the women in exotic couture connoting sex are more rapidly edited, aesthetically brighter and far less distressed than the footage of 'old Ireland': an Ireland that Clancy admits was in 'tatters'. This culture shock is itself far more current than the traditional tale of the innocent abroad would at first appear, evoking the themes of Gilsenan's earlier work, most fittingly his short film, Zulu 9 (2001), which follows the transport of an African asylum seeker to Ireland. It is easy to see the parallels here. As Herr notes on the earlier film, the "panic and confusion [of the refugee] are heightened by the likelihood that her destination was always a vague phantom - a notional Ireland where people have their own, foreign ways of being and which she has yet to imagine herself." (2007: 117.) In the context of The Yellow Bittern, Clancy too arrives in a society onto which he could not project himself. Moreover in his implied status as an acquisition of Diane Guggenheim's, he became a "transnational" or "fetish object", which when transcribed to the condition of the migrant (as "cargo - confined transported") brings to mind painfully up-to-date examples of the trafficking of people who become "identified with the experience of liminality as well as with the past." (112; see also Marks 2000: 78-79).

Such observations become evident in the film's transition from 'Boyhood' to 'Manhood'. The first chapter ends with Clancy alone with Diane in a house 'straight out of a Robert Frost poem'; a location that becomes dangerously isolated when Diane takes an overdose of pills after, according to Clancy, he rejects her sexual advances. Her consequent rescue and institutionalisation was a turning point: Clancy had to take responsibility for his life. The period of 'Boyhood', of innocence and of a liminal, 'kept' existence therefore came to an end.

'Manhood', then, charts not only the rise and fall and rise again of the Clancys and Tommy Makem, but their increased political awareness. The songs they added to their repertoire - "Sam 
Hall”, “The Wild Rover”, "The Wild Colonial Boy", all featured here - radiated with what Bob Dylan, in an archive interview, observed as 'exuberance and attitude'. This confrontational standpoint coincided with the group's decision to support the Civil Rights movement. This was an unpopular decision in the eyes of their fans, but for Clancy was necessary, as it addressed the inequalities hitherto suffered by the Irish migrant; a fact that becomes applicable and personal in the light of The Yellow Bittern's earlier themes. If 'Boyhood' encapsulates the wonder and disorientation of the young Irishman, while complicating this stereotype's basis in reality, 'Manhood' does the same with the image of the politicised, rebellious Irishman in America. This figure, according to McLoone, in "[f]acing the considerable disadvantages of a despised and feared minority, consigned to the most inhuman and exploitative jobs in the labour market, [became] organised and rebelled, eventually gaining acceptance within the dominant culture and ultimately changing the culture itself in radical and irrevocable ways." (2000: 51). Once again it is art that intervenes to problematise the meaning of Irishness here: the footage of Irish dancers weaving between the Clancys and Makem and the gimmick of the quartet wearing matching Aran sweaters seem to pander to popular conceptions of ethnicity; just as the lyrics and timbres of their songs have the capacity to escalate to forceful, confrontational and visceral crescendos.

Ultimately, The Yellow Bittern is, as a documentary, a chronological trajectory of a life that nonetheless does not tell the whole story. In keeping with Liam Clancy's love of poetry, Gilsenan's plundering the film archives depicting the changes in Irish and American culture adds a lyrical truth to the tale that is told. Yet in doing so it manages an evocation of Irishness, and of Ireland's past, that succeeds in commenting on the present condition of national identity, and consequently is a worthwhile companion piece to Gilsenan's other documentaries that explore the lives of prominent, and public Irish figures (such as The Ghost of Roger Casement (2001); Paul Durcan: The Dark School (2007)). Indeed, I would argue that this interrogation of Irishness is far more important than the precise detailing of facts. For in this context it is fruitless to question the motives of the teller or where the rupture between documentary and fiction occurs, but rather to pay attention to its understanding of politics and the condition of contemporary society. Better, then, to remember, as Jean-Luc Godard states, that "all great fiction films tend towards documentary, just as all great documentaries tend towards fiction" (in James 2010: 37).

\section{Works Cited}

Brereton, P. 2009. "Branding Irish Cinema: reflections upon Celtic consumer society and social change in Dublin”. Irish Marketing Review. 20: 2. 27-39

Herr, C. 2007. “Images of migration in Irish film: thinking inside the box”. McIlroy, B. (ed.) Genre and cinema: Ireland and transnationalism. New York: Routledge

James, N. 2010. "Syndromes of a new century”. Sight and Sound. 20: 2 (February). 34-38

Marks, L.U. 2000 The skin of the film: intercultural cinema, embodiment, and the senses. Durham, NC: Duke University Press

McLoone, M. 2000. Irish Film: the emergence of a contemporary cinema. London: British Film Institute.

Robert Furze is a PhD candidate at the Faculty of Communications, Dublin City University. His research interests include the global history of digital and analogue cinema, the semiology and ideology of the moving image, and the interrelationship between modern art, architecture and film. 


\section{Donal Donnelly: An Appreciation}

Michael Patrick Gillespie

Donal Donnelly was born in Bradford, Yorkshire, on July $6^{\text {th }}$ in 1931 , and died in Chicago on January $4^{\text {th }} 2010$. Shortly after his birth however, Donnelly's family moved back to their native Ireland where he first made his mark as a performer. He began on stage as a young boy, in productions at the Synge Street Christian Brothers School in Dublin, and, after an apprenticeship at Callaghan's outfitters on Dame Street, Dublin, he took up acting first at the Gate Theatre and then at the Globe in Dun Laoghaire. The career that followed established him as a quintessential Irish stage and film actor.

By many accounts Donnelly considered the theatre rather than the cinema his primary area of work, and certainly early exposure to the stage had a formative effect. In fact much of Donnelly's professional career and a great many of his acting successes took place on the stage. He first gained international attention for his performance in the role of Private Gar in the première of Brian Friel's Philadelphia Here I Come. For the next four decades Donnelly earned acclaim for roles in numerous Broadway and London dramas. Work on various plays by Friel's yielded some of his strongest stage performances, gaining him particularly recognition for efforts in a 1979 Broadway production of Faith Healer and again in New York in 1991 in Dancing an Lughnasa.

Despite these successes, at least one friend and colleague in the early 1960s, the Irish actor, teacher, director, and writer, Sam McCready, felt that Donnelly's efforts on stage did not match his cinematic work. In a recollection of Donnelly, McCready made the following observation to me:
My belief is that Donal never reached his full potential as a stage actor because he was rarely challenged - as he was by Huston. Especially in the US, he could get away with whimsy and charm but he was capable of more: the ability to touch the deeper pain of a character, the sadness masked by clowning, wit, alcoholism, and so on, which gives rise to great performances in the Irish tradition. That was what he found in the Playboy: the loneliness, the isolation from an abusive $\mathrm{Da}$, and the discovery that he had within him the potential to change this - an epiphany, if you like.

As the final sentence makes clear, McCready had great respect for Donnelly's work in the theatre, but he also offers keen insight into what factors informed Donnelly's best performances both on stage and in film. While the role itself stood as significant, the director had a pronounced effect upon Donnelly's performance.

When not on stage, Donnelly performed steadily in both films and television. Most of his film work was done in England and Ireland. Beginning with a minor role in John Ford's 1957 trilogy The Rising of the Moon and continuing through to This Is My Father in 1998, Donnelly worked in the cinema for over forty years. In many efforts, he demonstrated workman-like skills in supporting roles from Young Cassidy through Love and Rage. Like many Irish actors before and since, Donnelly appeared in some American films, including a distinguished performance in the otherwise forgettable The Godfather, Part III, directed by Francis Ford Coppola. However, two films stand out as distinguishing his career. The Dead (1987) directed by Huston, and Korea (1995) directed by Cathal Black offer profound examples of the impact that Donnelly had on Irish film-making. 
For the remainder of this essay, I would like to explore his achievements in each.

Donnelly's portrayal of Freddy Malins in The Dead reflects both his own genius as an actor and the deft approach that John Huston took in adapting James Joyce's short story for the screen. As Huston did with the entire screenplay, Donnelly made the character of Freddy Malins his own while remaining within the structure of the individual that Joyce had created. In consequence, his performance beautifully expresses the distinctiveness of his interpretation without trying to change the role of the character into more than what the screenplay outlines.

Certainly, Freddy's drunkenness is a great problem for the character. I suspect it is very difficult to convey the nature of an individual who is impaired in any fashion. Presenting a character who is drunk as more than a stumbling fool strikes me as a particular challenge. This is especially so when the role itself is set in the narrow time period of a few hours while the filming of it takes weeks to complete. Retaining the continuity of Freddy's inebriation from day to day while shooting and reshooting scene after scene requires tremendous powers of concentration and recall. Nonetheless from his opening appearance as he tries to manoeuvre his way up the stairs to join the guests at the Morkans' party to his final words directing the cabman as he and his mother and Mr. Brownee leave the house, Donnelly has the perfect pitch. We never forget that Freddy has taken too much to drink, yet he never becomes a caricature. The effect of alcohol shapes but does not define Donnelly's representation of Freddy in a masterful fashion.

The distinctiveness of Freddy's character goes beyond simply that of a man who has had too much to drink. Donnelly gives it a unique stamp early in his performance as he tells the story of his father's bashfulness at urinating in front of other men. Without giving the narration a heavyhandedness that would turn it into a slapstick routine, Donnelly conveys Freddy's blithe lack of awareness of the embarrassment his recitation creates in Gabriel Conroy and the consummate solipsism of a man who believes such a banal account of interest. In this brief exchange he lays down the defining features of Freddy Malins that will unfold over the course of the film.

In this scene and elsewhere, Donnelly has Freddy speaking with a slight stammer, a detail not presented in Joyce's story. As with his inebriation, Freddy's stutter is understated, but contributes marvellously to our sense of the character. It combines an impression both of vulnerability and of strength as he determinedly engages in a range of conversations with a range of people who all seem put upon by his discourse. As he attempts to explain to Browne why monks do penance for others, for example, there is a trembling in his tone and an eagerness and earnestness in his expressions, yet he never quite manages to come to a coherent elucidation of what the holy men are doing or why they are doing it.

Donnelly also deftly catches the stunted features of Freddy's emotion growth, representing in him a middle-aged boyishness that gives his character a poignant yet slightly foolish aura. Bracing himself to meet his mother and aware both of his transgressions and of her disapproval, Freddy's character falls into the frame of a young boy apprehensive of being scolded. Timidity and eagerness to please combine deftly with a certain disregard of all he has done to upset her that mark the exchanges he has with his mother (wonderfully played by Marie Kean).

Of course, Donnelly is far too good an actor to rely on a single trait to distinguish his character. At the dinner table, people begin talking about distinguished opera singers. With the lack of concern one finds in children and drunks, Freddy shifts talk from a discussion of opera tenors with a statement on the merits of a Negro singing in the Christmas pantomime. When Browne, who at this point is also feeling the effects of alcohol, dismisses the effort, Freddy responds with some violence, defending the singer and implicitly accusing Browne of racism, in an exchange that ends with a confrontation over Browne's use of the name Teddy rather than Freddy. It is a wonderful culmination of what Donnelly has already suggested as a friction between Freddy and Browne shown in an earlier scene with Freddy's overblown praise of Aunt Julia's singing. 
Even when Donnelly has no lines, he shows a wonderful presence. During Mary Jane's piano playing, Aunt Julia's singing, and Mr. Grace's recitation, Donnelly's face conveys just the right impression for the occasion. As Freddy, he knows how to watch in a manner that contributes to the audience's sense of the scene without distracting them from the central concern by his own behaviour.

Donnelly also displays an admirable touch for physical comedy. Near the end of the dinner, he unselfconsciously helps himself to celery arranged in a vase in front of him, and is rewarded for his efforts by his mother treating him like an errant child for not restraining himself until the pudding is served. Donnelly also manages a nice bit when he tries to capture the decanter being passed along the table, only to be thwarted by his mother and other guests. He handles all of these exchanges as comic moments without ever slipping into exaggeration or slapstick.

Throughout the film, Donnelly shows a wonderful knowledge of his character and a great sense of control. As Freddy he is not afraid to look the foolish drunk, yet he can walk a fine line between going too far and looking unconvincing. A gesture as simple as taking a chair down a flight of stairs shows clearly his inebriation yet never goes so far as to look ridiculous.

If his role in The Dead allows to show him a kind of extravagance, albeit tightly controlled, in his representation of Freddy, Donnelly's portrayal of John Doyle in Cathal Black's film Korea presents a very different challenge and makes very different demands upon the actor. Doyle is a pensive man with deep felt emotions but with little skill or desire to articulate them. Bitterness and frustration have come to inform Doyle's life, and the result is a mass of contradictions that, because of the nature of the character, are revealed to the viewer only in carefully calculated stages.

Donnelly's characterization of Doyle grew out of a collaborative effort with director, Cathal Black, and the patience that was inherent in Donnelly's approach to acting allowed the nature of Doyle to emerge in a measured but revelatory fashion. Shooting in Cavan on a limited budget meant that conditions were not always ideal, yet Donnelly embraced being part of the production community. Indeed, as Black noted to me, Donnelly felt a strong commitment to indigenous Irish filmmaking and was happy to be among others with similar dedication.

Although the characters were markedly different, the same techniques that distinguished Donnelly's interpretation of Freddy Malins gave great power to his portrayal of John Doyle. In scene after scene Donnelly's facial expressions, particularly his eyes, enhance and enrich the dialogue without ostentation or distraction. His movements incorporate gesture as demonstrative statement while exuding a stillness that tempers the tensest scenes with tranquillity.

The effort is particularly challenging, for Doyle is walking anachronism. He pursues an occupation, eeling, that is dying out in Ireland and is threatened by the rural electrification project. He nurses frustrations that go back to his participation in the civil war, and cultivates a grudge against an old enemy, developer Ben Moran, who was on the opposite side in the Civil War. Added to the friction is Moran backing the local electrification project because he hopes to profit from an increase in tourism while Doyle opposes tourism because he fears he would lose his license to fish so that stock can be built up for tourists. Donnelly underscores this conflict, as did with the nature of Freddy, through a dark sadness that underlies without overwhelming the character of Doyle.

Part of this animosity he feels against Moran leads Doyle to attempt to send his son Eamonn to America, going so far as to buy the ticket of passage, rather than allow a romance with Eamonn and Moran's daughter, Una, to flourish. The underlying concern is that Eamonn will end up in the American Army and be sent to Korea. This is what has happened to Moran's son, Luke, and local gossip accuses Moran of profiting from the money paid to the family after his son is killed in Korea. While this element of the narrative may make the film seem like a variation on Romeo and Juliet, in fact Donnelly's portrayal of John Doyle shifts the emphasis to issues of the scars of the Civil War, the stagnation of Ireland by the DeValera government, and the animosity that arises in the 
struggle between tradition and change. Economic stagnation with the band aid cure of emigration comes as an important issue throughout.

The dynamics between father and son stand as the crucial feature in the film, and Donnelly's generosity of spirit made that interaction so engaging. He shared a father-like bond with the young actor Andrew Scott, and made the latter's performance so much stronger for the advice Donnelly gave to him. (Scott, who came from Fermanagh, reciprocated by helping Donnelly perfect the Cavan accent for which the script called.)

Like Michael Furey in Joyce's story “The Dead” Eamonn becomes ill after seeing Una on a wet night. Una defies John by coming to the house to see the ill Eamonn. After his recovery, Eamonn confronts his father for the first time while they are fishing on the lake. Returning to shore, Una is waiting on the jetty. Reluctantly, John takes Una's hand of support as he alights from the boat. The scene, devised by Donnelly, mirrors an earlier one in which Doyle had helped Una out of a boat after she and Eamonn had visited Luke's grave, giving a sense of completion to the process of reconciling.

As portrayed by Donnelly with patience and energy, Doyle is neither a victim nor a victimizer. He comes across as a complex man, not a tragic figure but an individual with tragic, self-inflicted wounds. Donnelly's deft representation makes the film as much about the love story of a father and a son as about that of Eamonn and Una. Indeed, the contradictions within Doyle's nature and his conflicted feelings toward his son make their relationship far more interesting than the hormone fueled desires of Eamonn and Una.

Over the course of his career, Donal Donnelly established himself in the cinema as a marvellous character actor. While that may seem to signal a limitation in his ability, quite the contrary is the case. Donnelly may well have worked as a miniaturist, but the art he could produce within the tight confines of such characters shows a creative ability not always found in the conventional leading man. Donnelly represents a generation of Irish actors (David Kelly is another fine example) whose flexibility and range are manifest in subtle variations and the world of Irish film is richer for them.

Michael Patrick Gillespie is Professor of English at Florida International University. His latest book is The Myth of an Irish Cinema: Approaching Irish-Themed Films, Syracuse University Press, 2008. 
Sketching Success: Brown Bag Films go to the Oscars

Sinead Gillett

The first decade of the new Millennium witnessed a number of noteworthy accomplishments for the Irish audiovisual industry. The greatest success of all however has undoubtedly been the considerable growth experienced by the Irish animation sector. Powered by indigenous companies, built from the bottom up by talented and innovative practitioners, the animation sector in Ireland has established an international reputation for quality content production and is now the largest provider of full-time and permanent employment in the Irish film and television independent sector. Over the past decade or so these companies have proved their worth on the world animation stage; accruing substantial international sales and distribution, as well as critical acclaim and recognition. The latest achievements of the Irish animation sector come with the recent Academy Award nominations for two home produced films, Cartoon Saloon's The Secret of Kells (Moore 2009) in the Animated Feature category and Brown Bag Films' Granny O'Grimm's Sleeping Beauty (Phelan 2008) in the Short Animation category, as well as the nomination of Irish animator Richie Baneham in the Visual Effects category for his work on Avatar (Cameron 2009).

For Dublin-based Brown Bag Films the 2010 awards mark their second Oscar campaign. The company was first nominated in 2002 for Give Up Yer Aul Sins (Gaffney 2001), also in the Short Animation category, which - in a double coup for Ireland - they shared with Irish animator Ruairí Robinson and his film Fifty Percent Grey (2001). With two prestigious Oscar nominations along with a host of awards from international festivals, Brown Bag Films has established itself as a producer of world-class animation. From humble beginnings to Hollywood status, this essay takes a look at the acclaimed animation studio and the films that have brought it into focus.

Up until the mid 1980s the animation sector in Ireland developed at a relatively similar rate to that of other Western European countries; inextricably linked with the arrival of television, the sector slowly built momentum, with the national broadcaster commissioning small-scale projects from indigenous talent, while the advertising industry provided business to commercial studios. In 1985, the Industrial Development Authority (IDA), recognising that animation was a labour intensive growth industry, implemented a campaign of industrialisation by invitation aimed at enticing large US studios to Ireland. An attractive package of incentives, consisting of employment grants and a low rate of corporation tax (10\%), was targeted at companies looking to relocate outside America. Aided by Ireland's low wage cost and English speaking status, the impact of this package was immediate, resulting in the arrival of three major studios - Sullivan Bluth, Emerald City and Murakami Wolf. The largest of the three, the Sullivan Bluth Studio, was the first animation company to rival Disney on any grand scale.

A boom in animation production ensued, with employment peaking at 530 people in 1990 . In order to meet the demand for skilled labour, animation courses were established at third-level institutions: Assisted by the Sullivan Bluth Studios, the animation department at the Senior College Ballyfermot produced classically-trained graduates, while the programme at the Dún Laoghaire Institute of Art, Design and Technology (IADT) focused more on artistic 
experimentation. What had constituted a small cottage industry in 1985 had, within a relatively short period, transformed into a thriving sector.

However the boom did not last. A number of factors, including financial difficulties experienced by the American companies and Ireland's diminishing competitiveness in the face of the new international division of cultural labour, combined to effectuate the decline of the sector. By the mid-1990s Murakami-Wolf had been substantially downsized and both Sullivan Bluth and Emerald City had closed their doors.

It is during the demise of the American studios and the dark days that followed, when the industry lay in ruin, that the history of Brown Bag begins. The company was established by Ballyfermot students Cathal Gaffney and Darragh O'Connell in 1994 in order to produce a short television series for RTÉ. They had a difficult time locating start-up finance for their venture, such was the poor reputation of animation in Ireland at the time. When the project was completed the partners were unable to find work in Ireland and spent a number of years competing with Asia for service contracts, before taking on some small-scale advertising commissions as the dot-com boom began to take off.

Up until this point Brown Bag Films was operating with very low turnover and very much under the radar of public awareness. This was soon to change when a short film they made under the Frameworks scheme struck a chord with the popular imagination, impressing both audiences and critics alike.

Give Up Yer Aul Sins (2002) takes the form of a story within a story. Mary, a young schoolgirl in 1960s Dublin, is chosen to recite the tale of John the Baptist to a visiting television crew. In a thick inner-city accent peppered with colloquial language, she delivers a colourful version of the bible story. Her narration, which constitutes the majority of the film's soundtrack, is in fact a real-life recording that was taped during the 1960s at the Rutland Street primary school in Dublin. Having heard the compelling take on the Saint's life played on RTÉ radio, Gaffney was inspired to create a visual package for it. The evocative recording lies at the heart of the film's success; its somewhat intangible quality infusing it with a rawness no actor could imitate. The child's provincial turn of phrase and imaginative interpretation of the story content combine to a comic effect enjoyed by a wide audience. For many, pleasure in consuming the film can also be attributed to a sense of nostalgia for more innocent times and an Ireland and "Irishness" that are in many ways fading into distant memory.

As Mary recounts the tale, the on-screen action cuts between the first story - Mary in the classroom - and the second, that of John the Baptist. The sepia tone of the 2D animation, along with the hand added blips, the refocusing of the camera and deliberate appearance of a boom mike in frame as Mary narrates, combine to present the piece as archival footage. Together with the attention to detail evident in the opening images of 1960s Dublin, this documentary style reflects a deep respect on the part of Gaffney for the original recording. Indeed every aspect of the animation, from the lip-synching of Mary as she struggles to articulate the story, to the simple bible characters, whose actions closely mirror Mary's word, serve to frame and compliment the source material rather than overshadow it.

Following the Oscar nomination for Give $U p$ Yer Aul Sins Brown Bag was commissioned by RTÉ to produce a seven part television series based on the 1960s recordings. In the same style as the original short, each episode depicts a child telling a bible story to 'the men from the television'. Proving itself to be a commercial as well as a critical success, the series later became a best-selling DVD. With a heightened profile, both domestically and internationally, Brown Bag Films was able to take a stronger foothold in the animation industry and began to slowly but steadily expanded its operation.

In between a busy production slate (split across a commercials unit and a television unit), Brown Bag has made a further three short films under the Frameworks scheme; The Boy who had no story (Hickey 2004), Ding Dong Denny's History of Ireland (Gaffney 2006) and Granny O'Grimm's Sleeping Beauty (Phelan 2008). While the first two films were successful in their 
own right, it is the latest offering from Brown Bag that has once again catapulted the company into the public eye, earning them their second prestigious Oscar nomination in the eight years.

Granny O'Grimm is the creation of Irish comedienne Kathleen O’Rourke. Having seen the "Granny" skit performed on stage, director Nicky Phelan knew that the vibrant character would transfer well into the animated form. With both O'Rourke and Brown Bag on board he was able to realise his vision.

It is difficult to miss the parallels between Brown Bag's Oscar nominated shorts. Like Give Up Yer Aul Sins, Granny O'Grimm takes the form of a story within a story, this time starring Granny as the embedded heterodiagetic narrator. Under the guise of the "bedtime story" she delivers a dark version of Sleeping Beauty that unwittingly terrifies her granddaughter. Similarly to Give Up Yer Aul Sins, the humour in the piece derives from the narrator's interpretation of the story. In this case, Granny, bitter about her old age and the thoughtlessness of younger generations, empathises with the bad fairy, negotiating the narrative of the fairy-tale to facilitate her own emotional release. Her cathartic rants are flavoured with a distinctly Irish accent and colloquial turn of phrase, further adding to the film's comedic appeal.

Ding Dong Denny's History of Ireland also plays within this formula. In this instance a working-class Dublin man gives his version of the history of Ireland to a bewildered American tourist who has mistakenly wandered into a pub. The narrative hook of all three texts is not the story being told, rather the story of the story being told; each film hinging on the interpretation and delivery of the story by its embedded narrator. These films have clearly taken inspiration from the Irish seanchaí tradition, each one celebrating the art of storytelling and the fact that there is more than one way to spin a yarn.

While not quite inverting the traditional hierarchy of audio and visual in motion film, the equal status that sound and image occupy in these three texts certainly turns it on its side. In what is often a highbred relationship, the animation in these films serves to punctuate and embellish the verbal narration, "bringing to life" both the story teller and the stories they tell. The best execution of this to date is found in Brown Bag's most recent offering.

The animation style employed in Granny O'Grimm shifts as the visual action moves between two narrative levels. At the first level, we are presented with a 3D construction of the bedroom scene. Granny looms over the frightened child as she delivers her macabre tale. The clever use of light and shade combines with the performative gesticulation of Granny and the cadence of her speech to create tension in the film. The use of light and shade, together with subtle changes in countenance and close attention to detail in the mise-en-scène (including an intricate pattern on the wall paper and a picture of the Sacred Heart), also works to create a realist aesthetic for the frame story. The realm of the fairy-tale itself is represented in colourful 2D animation. Its traditional cartoon style contrasting strongly with the animation of the bedroom scene, creating a clear divide between the world of fairy-tale and what is presented as the "real" world of Granny.

In many ways Granny is real. Certainly she occupies a space outside the diegesis of the text itself. Directly addressing the public from her website and various social-networking pages, Granny is carving a name for herself as a national "treasure" - an animated equivalent to Dustin the Turkey.

It is apparent that Brown Bag has hit on a successful formula; creatively marrying strong verbal story-telling with both stylish and sophisticated animation. Taking their inspiration from one of the most celebrated traditions of Irish culture, their films are as pleasing - or at least as entertaining - to the ear as they are to the eye.

While their creativity in film-making has obviously earned them critical acclaim, it is worth noting that Gaffney and O'Connells' creativity in business is equally at the heart of Brown Bag's success. It is surely no coincidence that both Oscar nominated shorts are so easily transferrable into television series; the "story within a story" formula clearly holding both commercial and critical value for the company. 
In the case of Give Up Yer Aul Sins, more 1960s recordings were available to provide content for the series. For Granny O'Grimm the catalogue is far larger; with a wealth of fairytales for Granny to twist, this is one old lady who will undoubtedly earn her keep. Perhaps, with the success of the forthcoming series and the continuation of her celebrity status, "Brand
Granny” may even break into that coveted ancillary market all producers of animation thrive to reach - the lucrative domain of merchandising.

Sinead Gillett is a $\mathrm{PhD}$ student in the Department of Film at Trinity College Dublin. 
Helen (Christine Molloy and Joe Lawlor, 2008)

Padraic Killeen

One of the 2009's better received films, Helen, is a work largely funded and shot in Britain, but directed by ex-pat Dubliners Christine Molloy and Joe Lawlor, and with a fair degree of Irish money and amateur talent coursing through it.

It is not, however, to simply extend definitions of Irish film for the purposes of an annual review that we should fix our eyes on Helen, but rather to reflect on the continued rise of Molloy and Lawlor. Since winning the Best Short award at the Edinburgh Film Festival in 2004 for the enjoyably sinister one-shot, Who Killed Brown Owl, the pair have steadily developed a unique vision and methodology. Blending amateur theatrics and socially-minded community projects with high-brow technical practise - they only shoot on $35 \mathrm{~mm}$ cinemascope, and their shots often demand enough choreographical precision to make Busby Berkeley weep Molloy and Lawlor can be situated in an otherwise barely inhabited film grouping, that of the "Irish auteur".

They'd likely balk - and giggle too, one hopes - at such a suggestion but only auteurs take as much interest in methodology as this pair do. Trading under the name "Desperate Optimists", Molloy and Lawlor, who are also a married couple, have gradually earned a reputation for experimentation and artistic adventure with a series of seven shorts, Civic Life, produced between 2003 and 2007. Funded via community projects in the UK and Ireland, the seven shorts have helped Molloy and Lawlor develop a formal approach and style - amateur casts, small budgets, an emphasis on long, meandering takes, and a narrative concern with the paradoxical contingencies of everyday life - that pays off handsomely in their feature debut Helen.

The latter has been favourably compared with
Michelangelo Antonioni's classics L'Avventura (1960) and Blow Up (1966) and shares both narrative and formal resonances with each. However, in interviews Lawlor also often points to the minimalism of Danish master Carl Theodor Dreyer as an influence, while echoes of both Claude Chabrol and David Lynch, too, are plainly detectable.

Unsurprisingly, Helen was financed on the back of the success of the Civic Life series. When a number of regional arts bodies in the UK and Ireland came to Molloy and Lawlor to commission new shorts, the duo recognised an opportunity and convinced the bodies in question to pool resources in the interests of shooting a feature-length work. As part of the arrangement the team agreed to produce a short, Joy, which now serves as a prelude of sorts to Helen. Joy won prizes at the International Film Festival Rotterdam and the Darklight festival in Dublin in 2008, anticipating the prizes that Helen would go on to receive in 2009. Helen picked up best film and actress awards at the important Festival Premiers Plans d'Angers, while D.O.P. Ole Birkeland deservedly claimed the Best Cinematography Award at the Dublin International Film Festival 2009.

The feature's narrative opens with the troubling disappearance of a schoolgirl, Joy, but quickly switches focus to Helen, a classmate who - by virtue of her physical similarities to Joy - agrees to stand in for the missing girl in police reconstructions. As the narrative progresses, Helen - who has lived her young life in the care system - gradually finds herself in thrall to the biographical details of Joy's life, and proceeds to foster strange ties with both the missing girl's parents and her boyfriend. More pointedly, as she reaches her eighteenth birthday 
and prepares to leave social care, Helen is in the process of discovering - or constructing - a fresh independent identity, and the film meditates on the myriad contingencies that govern the shaping of such an identity.

In its echoes of L'Avventura, the film does not repeat that film's most unsettling trick Antonioni's infamous manipulation of his audience, in which he lulls the viewer into concern for a missing female character early in the film only to make us ultimately forget about her as the narrative presses on. This latter aspect of L'Avventura was memorably described by Pascal Bonitzer as "the disappearance of the disappearance of Anna." In Helen, however, there is no disappearance of the disappearance of Joy. Molloy and Lawlor never allow the viewer to lose sight of the missing girl. For one thing, her shell-shocked parents' anguish is palpable and heartrending. Meanwhile, Joy haunts the film in other ways, most notably via Helen's own growing identification with her, which comes to involve walks out to the woods where Helen confides in her departed double.

If the narrative is enigmatic then the cinematography and the camera movement are at times positively ethereal. With its long panning movements the camera oscillates between the lyrical (a drifting, relatively neutral presence that calls to mind the films of Theo Angelopoulos) and the predatory (a prowling intensity which recalls both Lynch and Michael Haneke). The mise-en-scène, meanwhile, amplifies the exceedingly modern and pristine qualities of school gyms, police offices, plush apartments, and - most notably - the architecture of public buildings. (The latter concern, one imagines, would have been a gesture toward the funding bodies themselves, who were eager, no doubt, to emphasise environmental and public works).

In the film's lead role non-professional Annie Townsend puts in a captivating and subtle performance. Nonetheless, it's true that some of the other amateur turns are rendered less successfully. Those reviewers, however, who rounded negatively on the acting - consumed, it seems, by a concept of cinema as offering only narrative pleasure, and apparently blind to the more profound formal possibilities of the medium - are waging a bet that verisimilitude actually matters a great deal to Molloy and Lawlor. One suspects that it does not. In keeping with the Civic Life series the film is not a product as much as it is a process. The amateur actors are core to that process, and ultimately what gets filmed is "the film".

Similarly, though the long-take clearly appeals to Desperate Optimists as an aesthetic strategy it is also incorporated into their methodology as an expedient approach to filming. In short, it avoids the time-consuming activity of constantly setting up shots. As it turns out, the 79 minutes running time of Helen was edited together from just 300 minutes of footage. Those who are unwilling to appreciate this methodology will inevitably find some scenes protracted and some of the performances unsophisticated. Yet this would be to blind oneself to the manner in which such a sense of protraction is a key element of the film. The film is even punctuated by fades-to-black that do not offer quick transitions but instead last a pronounced period of seconds - much longer than fades ordinarily do. In short, if the film is about identity and its construction then everywhere the formal aspects of the film resonate with this theme.

That is not to say that there are not occasions when Lawlor and Molloy's methodology does not impede the film somewhat. One scene between Helen and Danny (Danny Groenland), in particular, really would have benefited from being re-shot. Yet even here the amateur values (Groenland's intonation is quite off-beam) carry a certain currency of "process" that imbues the film with its own unique property.

In his seminal essay "Music as a Gradual Process," Steve Reich describes the experience of listening to "process music" - one of the most influential innovations in $20^{\text {th }}$ century composition - with a visual analogy. This music, he says, involves "a process happening so slowly and gradually that listening to it resembles watching a minute hand on a watch you can perceive it moving after you stay with it a little while.”

Perhaps such a clock-watching analogy might be opportunely borrowed here to describe the experience of viewing Helen. In everyday parlance, of course, the concept of watching a clock tick by is synonymous with an experience 
of insufferable boredom. But, just as it could not be said of Reich's rich musical legacy, one could never describe Helen as boring. Rather, it unfurls before us with what is an exotic languidness, a seductive temporal drift in which every thing and every gesture is magnified tenfold, and transformed as a result.

Importantly, in slowing time down the film employs technological means - there is a beautiful, lyrical use of slow-motion in the film's opening sequence - but most of the time it does so by dwelling on the empty intervals that pepper the protagonists' verbal interactions. (The dialogue, it should be noted, is commonplace to the point of becoming strange or unsettling. In other places it is silly and absurd. In other places still, it is quite poignant).

This concept of "process", meanwhile, and its echo of Reich is not totally coincidental. Helen's score was produced by Dubliner Dennis McNulty, a conceptual artist who first came to prominence in the 1990s with experimental electronic outfit Decal, who wore their debts to Reich proudly on their sleeves. McNulty's score darkly emboldens the narrative's meditation on identity, via a signature theme that starkly invokes Reich's celebrated "phasing" technique (in which at least two instruments - or recordings - simultaneously play the same notation but at contrary tempos, thus weaving in and out of one another in an alluring discord that occasionally produces tantalising harmonies).

Indeed, I would suggest that Helen in its entirety seems to question the currently popular concept of the self as the product of narrative identity, which has gained credence via the philosophy of Paul Ricoeur, Alasdair MacIntyre, Charles Taylor, and others. Just as McNulty's score emphasises an ineffable discord, the film too appears to ask where someone like Helen can look for narrative identity when the circumstances of her life (the unknown backstory of her parents) and her muted hopes for a future (she dreams only of the most mundane sense of home) suggest an essential disunity. As such the film charts a tension between narrative identity on the one hand and the sort of flickering episodic identity that the British philosopher
Galen Strawson has recently offered as a counterweight to the predominant narrative model of self.

Finally, in terms of the film's various Irish associations, one of the funding organisations involved the Dublin Docklands Development Authority, and the Irish Film Board also financed a print for festival distribution. As a result of the DDDA's investment, a quota of the film's exterior photography was shot in the redeveloped docklands area. This footage is knitted seamlessly into similar exterior shots filmed in Liverpool, Birmingham, and Newcastle, and it's interesting that despite the predominance of English accents the film never explicitly states which city it is set in. Moreover, the filmed locations each stress images of re-generation, which again lends itself quite seductively to the narrative's themes of identity construction.

There are other prominent Irish incisions into the film, not the least of them the amateur turns of Groenland as Joy's boyfriend and Sheila Hamilton and Betty Ashe as Helen's liaisons in the care system. Though they form only a minor aspect of the film, the general ease with which these unlikely Irish interruptions can sit within a predominately British landscape speaks perhaps to the hybridity that now weaves itself through Irish and UK identities, and in which Richard Kearney some years ago perceived the possibilities of a more positive "postnationalist" relationship between Britain and Ireland.

Meanwhile, whether Molloy and Lawlor can be triumphantly reclaimed as "Irish film-makers" or not is ultimately a peripheral point. In an interview I conducted with the pair last year Lawlor played down the significance of their ethnicity, saying he considers himself a European film-maker, while at the same time acknowledging the cumulative influence that his being Irish inevitably brings to bear on his general outlook. Molloy, more pointedly, declared that she does consider herself an Irish artist. By way of anecdotal evidence she explained that when they chose the working name Desperate Optimists back in the 1990s it was intended to playfully denote a specifically Irish meaning of the word "desperate" - i.e. 
denoting something shockingly bad or, in Molloy's words, “crap”. The joke was that they were crap optimists.

Despite their being "crap" at this optimism lark, however, things continue to pull in a positive direction for Molloy and Lawlor. Most notably, they are currently developing a new feature project, Mister John, with Samson Films, the Irish production company that spawned the massive international success of Once a few years ago.

Padriac Killeen is a $\mathrm{PhD}$ candidate at Trinity College Dublin. 
Ondine (Neil Jordan, 2009)

Paul McGuirk

Ondine is Neil Jordan's sixteenth feature film - and his eight set in Ireland. One of a number of smaller, personal films by Jordan, it is a muted, elliptical fable that, while growing out of a number of dark folk-tales, ultimately seeks to assert an optimistic and even romantic view of the world. In creating the story, Jordan - the great adapter of Irish cinema - takes elements of the German folktale from which the film derives its title, the Scottish Selkie tradition, and Hans Christian Andersen's “The Little Mermaid” and uses them to underpin a contemporary narrative that deals elliptically with issues of drug-culture, immigration, and the breakdown of traditional family structures in Ireland.

All the sources on which Jordan draws involve relations and relationships between sea-creatures of one form or another and humans. In the German version of Ondine, an immortal waterspirit, upon falling in love with a landsman and bearing him a child, loses her immortality and begins to age. The landsman, tiring of her, turns his attentions elsewhere. When Ondine discovers him with another woman, she takes her revenge. The Childe ballad, Silkie, tells the story of a seal-man who, having fathered a child on a lands-woman, later returns to take his son back with him to the sea kingdom of Sule Skerrie. This was the tradition that John Sayles tapped into in his 1994 adaptation of Rosalie Fry's novel, The Secret of Roan Inish, which he shot with Haskell Wexler in Donegal. Sayles' film tells the story of a young girl, Fiona, who, listening to islander's tales, comes to believe that her young brother had been washed out to sea in his infancy and raised by a Selkie. The Hans Christian Andersen's story of The Little Mermaid involves a young mermaid who falls in love with a prince and later saves him from drowning when he is shipwrecked in a storm. In order to be with the prince, the mermaid drinks the Sea Witch's potion that transforms her fishtail into human legs. The price that she must pay for this transformation is that walking on land is a constant agony and, in addition, she loses her voice and becomes mute.

These stories deal in various ways with the idea of difference and the difficulties and anxieties that arise when strangers come into host-communities. In the folk song, Silkie, although the story is told from the point of view of the landswoman, the Selkie gets to set out his position in the lyric also. In The Little Mermaid, the story is told from the point of view of the mermaid. So, in both of these narratives, the Other, the stranger, gets to articulate desires that impact adversely on the lands-people while the purpose of the story is to give expression to the anxieties of the host communities.

In Jordan's Ondine, the story is told from the point of view of Syracuse (Colin Farrell), a solitary alcoholic fisherman who, divorced from his wife, Maura (Dervla Kirwan), has jointcustody of their daughter, Annie (Alison Barry). The film opens with a rather dishevelled Syracuse fishing on his trawler - a fairly battered rust-bucket - on the sea off Casteltownbere (West Cork), and hauling a young woman (Alicja Bachleda-Curus) from the water in his nets. When Syracuse asks her if she is an asylum-seeker, she simply claims that she does not know how she came to be in the water.

Syracuse takes her to a ramshackle cabin in a secluded cove, where he keeps his boat moored, and tells her she can stay there as long as she likes. When he returns the following morning, 
he is surprised to find the woman still there. He takes her out fishing with him and she tells him that she has no memory of who she is, but that he can call her Ondine. Later, it emerges that Syracuse's daughter Annie's (Alice Barry) kidneys have failed and she, confined to a wheelchair, requires dialysis several times a week. At one of Annie's dialysis sessions, Syracuse, to pass the time, tells her a story about a fisherman who catches a woman named Ondine in his nets. Unimpressed with Syracuse's account, Annie does some research herself in the local library where she finds a number of books on Selkies and the story of Ondine. Her curiosity aroused, Annie makes her way out to her grandmother's cabin where she finds and befriends Ondine.

Syracuse's relationship with his alcoholic exwife, Maura (Dervla Kirwan), is fractious. Maura lives with Alex (Tony Curran) who has abandoned his own wife and children in Scotland and come to live in Ireland. Uncomfortable with her mother's relationship with Alex, Annie becomes increasingly drawn to Ondine whom she believes to be a Selkie. And it is here that Jordan's film strikes certain resonances with the Sayles version. In order to test the veracity of this belief, and also Ondine's attachment to her, Annie plunges herself and her wheelchair into the harbour waters at Casteltownbere during the annual regatta. Diving from the harbour wall, Ondine saves Annie from drowning. However, Ondine has been spotted by Vladic (Emil Hostina) - her Selkie husband.

Driving home, after a hard day's drinking, with Alex and Annie in the car, Maura is involved in a collision with Vladic, in which Alex is killed. As it happens, Alex has a kidney donor card and his tissue matches Annie's. At Alex's wake, Maura tells Syracuse to get rid of Ondine, and Syracuse, in a drunken stupor, takes her out to the seal island in Bantry Bay where he abandons her. Realising what he has done the following morning, he goes back out to the island and rescues her. When they return home, however, Vladic is awaiting them.

It emerges that Ondine is, in fact, a Romanian “drug-mule”, named Johanna. In an elaborate flashback, we learn that Vladic had entrusted a consignment of drugs to Johanna/Ondine and put her into the water when they were intercepted by the Coast Guard at sea off the south coast. Vladic wants the drugs returned. Annie claims they are hidden in a lobster pot at sea. In a confrontation on Syracuse's boat, Johanna/ Ondine throws Vladic, who cannot swim, overboard and he drowns. Johanna/Ondine is taken away by the Gardai and is about to be deported when Syracuse intervenes and marries her.

In Jordan's reworking of the folk-tale sources, the stranger, the Other, the asylum-seeker is figured as an attractive young woman. At no point does she appear to represent any sort of threat to either Syracuse or his daughter, Annie. She is quiet, refined, East European. Her singing seems to improve Syracuse's catches at sea. She undertakes teaching Annie how to swim. The world she enters, a modern fishing port whose serried ranks of industrial trawlers, effectively caught by Christopher Doyle's cinematography in all their dour, mechanical impersonality, is in many ways far removed from the picturesque coastal villages of which the Irish Tourist Board was once so fond - those nostalgic images designed to evoke some semblance of an imagined rural/maritime idyll. Jordan's fishing port is a cosmopolitan place. It is not the metropolis, but it pays little heed to "strangers", to "foreigners", to the Other. People come and go. No one pays any particular attention to Vladic, snooping around, asking questions about Ondine. No one passes any comment on Syracuse and Ondine strolling around the town, or shopping for designer dresses and underwear in the local boutique. Even the rather hapless local priest, whom Syracuse uses as a surrogate "AA buddy" - has little to say about Syracuse "sinning" with this strange woman. $\mathrm{He}$ is fatalistically reconciled to the fact Syracuse is just using him and that there is no point in expecting him to attend Mass or say a "few Hail Marys' in return.

Like the unsatisfactory story that Syracuse initially tells Annie about the fisherman who finds a woman in his nets, Ondine, the film, is 
telling us a story that is trying to make sense of some of the social and cultural incongruities of the recent past. This is a society cut adrift from the traditional customs and values derived from the cultural nationalism and Roman Catholicism that informed most of its social and political discourse for the best part of the twentieth century. What Jordan elliptically evokes is a society that is both literally and metaphorically drunk; a society that has lost touch with reality. The hubristic and exotic delusions of the "Celtic Tiger" era have been replaced by the grim realities of the Hibernian hyena. Here is a society that is fractured and disorientated. The old stories have proven inefficacious and it is necessary to generate new narratives in order to make sense of the changing circumstances. However, isolated and incapacitated, Annie goes back to another past, to old stories of another culture and tests them against a contemporary reality with mixed results: she misreads reality through a fairytale.

While the Ondine of the German folktale loses her exotic allure once she has fallen for the knight and borne him a son, Jordan's Ondine retains her air of foreign glamour right to the end. So, the anxieties to which the exotic gives rise are allayed: the fear that the exotic, once it has been accepted, will turn out to be not only ordinary but also, in a sense, profoundly debased, is assuaged. As a drug-mule, Ondine/Johanna had been used, abused, exploited and victimised by Vladic - the corrupt Other. However, there is never any suggestion that she is anything less than intrinsically good, and benign in her intentions. Even in moments of extreme duress, she remains eager to form a family with Syracuse and Annie, and we are led to believe that her "goodness" will ultimately copper-fasten Syracuse's redemption. There is never any question of her going back to her own place, never any question of her laying claim to that which belongs to Syracuse.

In the ballad, Silkie, the seal-man returns to reclaim his son. The Silkie remains Other. He is a "grumly guest"; he is not "comely". And he is of another place - "And when I'm far and far frae land, my home it is in Sule Skerie". He is the feared "foreigner" who insinuates himself into the host community for his own advantage, and when he has achieved what he set out to achieve, takes away what he considers his by right without any consideration for those whom he leaves behind because his allegiances lie elsewhere. Jordan's Ondine, on the other hand, is fully assimilated. She kills her seal-husband and thus cuts her ties with her other world, her home country. This is the perennial wish or fantasy of the host community: that, if, in what it sees as its generosity, it accepts "outsiders", they should assimilate and unequivocally cut their ties with their own culture - and by extension, remove any threat that that culture might pose. In Jordan's version, the fantasy is realised.

In the German Ondine, the Scottish Silkie, and The Little Mermaid, the sea-creatures remain other and are never assimilated. Because, Jordan's story is told for the most part from Syracuse's point of view, Ondine's otherness is never fully explored. The conflict at the heart of the narrative is between Vladic and Ondine/Johanna. Despite this, Vladic remains a peripheral character, a cipher, a hollow signifier of otherness and criminality. Alex, the other foreigner who is killed as a result of Maura's recklessness, is figured ambiguously also. Annie is mistrustful and fearful of him. He has abandoned his wife and children. Yet he carries a kidney-donor card, and effectively saves Annie's life.

There is never any real conflict between Syracuse's position and Ondine's. He accepts her without question right from the start. When he does abandon her on the island, it is in a peculiarly motivated drunken rage that has been prompted by Maura's own drunken exhortations. Syracuse's positioning within his local society is ambivalent also. He refers to his mother as a "gypsy" and Maura tells him that they do not serve "knackers" like him in the local bar, The Skipper. So, it is not clear whether Syracuse is a settled traveller, or whether "knacker" is just a term of abuse that rolls easily off Maura's drunken tongue. What is reasonably clear, however, is that Syracuse, like many of Jordan's male protagonists, operates within extremely fuzzy and blurred boundaries. Syracuse is a rather well-intentioned if somewhat hapless character. Things have not worked out for him but he is not responsible for anything bad 
happening. The two deaths that facilitate narrative resolution - that of Alex and Vladic are both significantly brought about by women associated with Syracuse, but not by Syracuse himself. This is a leitmotif that goes back as far as Mona Lisa (Neil Jordan, UK, 1986) and The Crying Game (Neil Jordan, Ireland, 1992).

Ondine is beautifully photographed by Christopher Doyle who captures the sullen, grey seascapes and landscapes around Casteltownbere in what must have been a very dull summer. The sombre tones of the images work very effectively in evoking Syracuse's eviscerated emotional life. Colin Farrell's performance also manages adroitly to convey tangibly something of the almost exhausted, emotional inertia from which Syracuse seems just a step away most of the time.

At a time when the Republic is in a state of political and economic turmoil, and the focus of many people's attention is on the collapse of the centre of power in the metropolis, Jordan leaves behind the city - its corrupt politicians, bankers and developers - and gives us a redemptive love story. The project and its ambitions contrast with his contemporary and friend Jim Sheridan who has decided on a transposition of Susanne Bier's 2004 family melodrama Brothers from Denmark to the US. The prolific Jordan is here once more working with his own screenplay, on a low budget, and on his own ground.

Paul McGuirk lectures in European Cinemas, Irish Cinema, Documentary Film, \& Film Theory at undergraduate and postgraduate level in Trinity College, Dublin, and The National Film School of Ireland at Iadt, Dun Laoghaire. He was awarded a PhD by UCD in 2007 for his thesis, From Modernism to Postmodernism: The Fiction \& Films of Neil Jordan. Currently he is working on a book on Neil Jordan's literary fiction and films. 
The Finite Televisual Narrative: Pure Mule, The Last Weekend (RTE, 2009)

\author{
Barry Monahan
}

It is testament to the vast ideological scope of television within the imagined community, and its central position relating to the dissemination and manipulation of ideas, that Irish programmes such as The Late Late Show, 7 Days and Primetime, are often cited for their profoundly influential role in holding a polemical mirror up to Irish society. Regarding the first of the three, Lance Pettitt goes as far as to state that the chatshow hosted by Gay Byrne was so significant in interrogating the ethics and attitudes of citizens of Ireland, and such a potent driving force for social transformation, that it could be considered a "Mid-wife to contemporary Irish liberalism" (2000: 166). ${ }^{1}$ However there is another sense in which television and televisual broadcasting can be seen to negotiate and present community to the community, and this operates through fictional programmes and is dictated by structural imperatives of the television series.

Most commonly played out in the format of the soap opera, the form allows a regulated number of characters to interact across an ongoing narrative development of infinite possibilities and connections. As the elasticity of the coordination of the human dramas and conflicts threatens narrative coherence, the format dictates that community is very clearly defined as containing the randomness of individual actions and interactions. This results, on a basic level, in the constant and concrete naming of locations: the public and private spaces in which dramas occur or are linked by gossip, accusation or eavesdropping.

1. Pettitt, Lance. 2000. Screening Ireland. Film and television representation (Manchester \& New York: Manchester University Press).
Furthermore, it is complemented by the very strongly "community-located" titles given to many of the most popular soap operas (from home) Bracken, Glenroe, Fair City, (and away) Eastenders, Coronation Street, Emmerdale. This apparent delineation of space and place also has a clear economic rationale: while stage sets can remain relatively (cheaply) unchanged, developing over time only as the given budgetary situation allows, actors can be woven in and out of narrative lines if and when they are needed.

In the case of some recent Irish television, exactly the opposite is the case, and it is with an innovative formal inversion of typical television practice that a new aesthetic has come to Irish screens. Last year, Element Pictures oversaw the production for RTÉ of Pure Mule, The Last Weekend, a two-part revisiting of many of the characters introduced four years earlier in the six episode series Pure Mule. ${ }^{2}$ Eugene O’Brien returned to work on the screenplay, and Declan Recks directed both of the new sections. These latter installations dramatise small community life in the same mid-west Irish town over one weekend "four years later", and blocked as "Friday/Saturday" and "Sunday/Monday". Where, in the first set, one weekend is replayed from six different - but interacting - characters' points of view, and each episode is titled with that character's name, the new episodes concentrate on two protagonists: Jennifer (Charlene McKenna) and Scobie (Gareth Lombard).

2. For an analysis of the first six episodes of Pure Mule, see Tony Tracy (2006: 172-74), Estudios Irlandeses Issue 1, http://www.estudiosirlandeses.org/Issue1/Film Reviews.pdf

ISSN 1699-311X 
The busy property development of the town that formed the backdrop against which the dramas occurred in the first installations, and perfectly reflected the zeitgeist of Ireland's then booming economy, has now become a frozen industry. The construction site on which Scobie and his brother Shamie worked is now abandoned, with houses left in various states of completion. Shamie has moved to Australia where Scobie is intending to move; a decision with which he grapples over this last weekend. Jennifer has been in London and returns with her boyfriend of two years, for her mother's funeral. In terms of narrative, the balance between death and unemployment-motivated emigration on the one hand is set against new romantic relationships and returning emigrants on the other, in a way that creates a dramatic fluidity that presents the community with certain vulnerable instability. As is the case with O'Brien's writing for the screen, this quality is offered aesthetically with perfect objective correlatives as sequence transitions dramatising indecision or mobility are shot at crossroads, borders of the town and rural spaces, or looking down roads that vanish into the distance. The strength of the visual writing is perfectly complemented with a cinematic style of lighting and framing designed by Owen McPolin. A visual restraint establishes a rhythm of cutting from long shots to close up as the eye of the camera adds to the reflective nature of the two protagonists who work towards a moment of self-knowledge. Jennifer and Scobie's enlightenment is marked in two cases when each looks contemplatively into a mirror; the cinematic shorthand for a personal epiphany, perhaps most famously used by Bergman in Wild Strawberries (1957).

O’Brien's powerful visual writing centralises specific props with metaphorical significance as perfect objective correlatives. In one scene Jen bursts onto a hall at which a wedding party has taken place. Distraught in confusion over her romantic situation and frustrated at the smothering and restrictive nature of the town and its inhabitants, she punctures a helium heartshaped balloon on the floor and then sitting at a table releases another. She watches as the red heart floats upwards and stalls, stopped by the ceiling. The lucidity of the metaphor reflects perfectly the connection between O'Brien's script and McPolin's realisation of it with Recks' direction.

The opening shots of each episode are held with a stillness that demonstrate how both the town and its people will be put under the microscope. In the last two, more specifically, the imagery of landscape and settings depicts not only an Ireland at a time of economic recession but a location that is frozen in time like a cinematic still offering itself up to scrutiny. The movement of characters, or the use of "outsiders" (whether Irish or not), further emphasises this quality and allows an exposure of the town and its community as a place that must be analysed. At a critical moment, amongst a crowd of locals, Jennifer shouts: "This is not who I am anymore, I swear ... it must be this ... Jaysus town ... all of you that bring it out in me.” This sense of looking inside from beyond is articulated in numerous shots in which characters observe others through door and window frames, or watch them through crowds of townspeople.

The set six-episode and then two-episode structure affords a certain narrative flexibility that accords well with the somewhat dysfunctional, fragmented nature of the community presented. Individuals move in and out of sexual relationships as easily as they seem to come and go from the town. The dénouement is as much an unravelling of interpersonal interactions and social cohesion, as it is a logical winding down of characters' narratives in typical resolved closure. The ultimate lesson that individuals learn is the extent to which they are restricted by their performed role within, and relationship to, the town's inhabitants and social structure. The collective community memory becomes an ideological apparatus in which individuals and their personal narratives get hopelessly caught. Escaping from that history (the broader collective narrative) becomes the aim of Jen and Scobie, and this is only possible after a moment of self-realisation which marks how embedded their stories are within the broader narrative of the town.

The typical soap opera offers integrity of community - even, and especially, in cases where the plot lines represent social fragmenta- 
tion, interpersonal arguments, or the arrival and departure of characters - where its narrative structure is centrifugal, diffused and infinite. It is precisely because of the finite and fixed form of the episodic structure of Pure Mule (and some other recent Irish television programmes like Prosperity (Lenny Abrahamson, 2007) ${ }^{3}$ that writers can play with the fragmentation of community, so that emigration, uncertainty about the future, and the problematic nature of relationships, can be addressed harmoniously both thematically and through narrative construction. This structural ambiguity, one that emerges from the creative imposition of the finite over the unlimited nature of human interactions, may also reside by implication in the title. Acknowledging a real-world association with the town in which they grew up, the writer and director have pointed to the double meaning of the phrase "pure mule": one that expresses a

3. For an analysis of Prosperity, see Díog O'Connell (2007: 239-41), Estudios Irlandeses Issue 3 http://www.estudiosirlandeses.org/Issue3/IrishFilm\& TV2007/pdfTheYearinIrishFilmandTV2007.pdf positive summary of a thing or event, the other suggesting the exact opposite. In the closing sequence, as Scobie, his mother and her fiancé drive down the road away from the town into his uncertain emigration, two characters met earlier drive alongside him in their car, and they scream elatedly the ambiguous words at each other.

Barry Monahan lectures in the history and aesthetics of Irish and other national cinemas, and film theory at University College Cork. His recently published monograph Ireland's Theatre on Film: style, stories and the national stage on screen (Irish Academic Press, 2009) considers the relationship between the Abbey Theatre and cinema from the beginning of the sound period until the 1960s. He has also published on contemporary Irish cinema from different theoretical and aesthetic perspectives in publications such as Genre and Cinema: Ireland and Transnationalism (McIlroy, Brian ed.) (New York: Routledge, 2007) and in Keeping It Real (Ruth Barton \& Harvey O’Brien (eds.) (Wallflower Press, 2004). 
This Sporting Life: Waveriders (Joel Conroy, 2008), Saviours (Liam Nolan and Ross Whitaker, 2007), “GAA on DVD”.

\author{
Harvey O’Brien
}

The documentary Ireland - Isle of Sport (1959/60) begins with a self-consciously iconic image of a Catholic priest, bedecked in collar and cloth, cheerfully throwing a sliotar [leather ball] through the air to a young boy poised and waiting with his camán [hurling stick]. The freeze frame of wholesome sportsmanlike ecstasy which gives way to the title card is a prelude to a film promoting Ireland as an ideal site for organisers of internationally-sponsored sporting events. Ireland, it tells us, is the cradle of a heroic tradition of sporting endeavour grounded in fairness and morality, but also forward-looking and open for business. It is difficult to view this scene now without a mental image of Dermot Morgan as Father Ted using false arms to conceal the remote control he has hidden under his jacket with which he is directing the electric wheelchair in which the comatose Fr. Jack is playing a blinder in the All Priests Over 75s Five a Side football match. Ireland has changed. Irish sport has changed. Irish attitudes towards Irish sport have changed.

Several recent non-fiction releases have thrown up some new perspectives on Irish sport and sporting endeavour. Joel Conroy's surprise hit Waveriders (2008) not only documents the unlikely image of big wave surfing in Ireland, but like The Irish Empire (1999) before it, makes a claim for a global Diasporic legacy of Irish surfing stretching back to the foundations of the sport. Meanwhile Liam Nolan and Ross Whitaker's Saviours (2007) was, in itself, a remarkable document of the face of multicultural, multi-ethnic Ireland as seen through the boxing scene, and took on unexpected poignancy in the wake of the death of Darren Sutherland in 2009. Sutherland's struggles with self-confidence were one of the film's key narrative threads, and knowledge of his difficulties then took on new meaning with the tragic end of his real-life story. Finally, the catalogue of "GAA on DVD" documentary collages by Sideline Productions reached over 100 in 2009 with the release of a number shockingly bare-bones DVDs of classic football and hurling matches from the 1960s and 70s that raise interesting questions about the value of the sporting past, how we choose to present it, and how we experience or re-experience it as consumers of images.

Arguably the most culturally non-specific of the three is Waveriders, which in spite of a soundtrack prominently featuring tracks by U2, The Undertones, and Rory Gallagher, and a plethora of footage shot off the coast of Donegal, works hardest at being international in outlook. The most appealing element of the film is the collision between imagistic and cultural traditions of the two 'Wests' - cold and rocky Ireland and warm and rockin' California. The film traces the story of surfing itself, highlighting the historical contribution of Derry-born pioneer George Freeth, whose championing of the sport he discovered virtually dormant in Hawaii is part of the lore of American surfing. Less so legendary is his Irish connection, and the film redeems this by inference in the manner of so many Diasporic histories. Freeth wasn't surfing at Bundoran with Jack London, but if the beginnings of the sport lie with an Irishman, isn't Irish surfing not so much a matter of a quaint and quixotic oddity as a key part of its culture? Certainly some of the interviews bear this out, tracing how the relative waning of the sport in the US as the Irish scene exploded makes Ireland 
an exciting place to surf rather than just another stop on the tour. The film also boasts interviews with international professionals including Kelly Slater (who, rather diplomatically, remarks 'I'm not too fond of the cold"), and the surf clan Chris, Keith, and Dan Malloy, whose Irish roots are shown to form part of their sense of adventure and tradition (they too find it a little cold in the Old Country, though).

Waveriders features some good, if generic, images of surfing. The imagistic incongruity of the green fields and stone castles that form the backdrop, and the late introduction of the tale a 'new wave' (an actual wave generated by the movement of tides around certain rocky outcrops) that is linked to Celtic mythology does not ultimately amount to a great deal of significance, and the plethora of Irish voices heard speaking of how the sport brings people together and creates a sense of unity does not, in itself, amount to anything grander by way of a cultural statement than simply the fact that this phenomenon exists and is legitimate. As a sports film it lacks the intimacy and focus of the likes of Dogtown and Z Boys (2001) in terms of the immersion in culture and a sense of the contours of the sport defined by its history and the evolution of its tradition. It also lacks the narrative excitement of a competition-based sports documentary like Hoop Dreams (1994) or Murderball (2005). This is not to say the film isn't worthwhile or interesting, but there is a sense that the pitch of a film about surfing in Ireland and the legacy of Irish surfers is ultimately more exciting than the product, as least insofar as it contributes something fresh to both Irish documentary and Irish sport.

By contrast, Saviours deals in a familiar register in sporting and documentary terms, but is a film of some distinction in its execution. There have been several films involving Irish or ethnic Irish boxers over time, not least of all the theatrically-released Southpaw (1999) profiling amateur boxer Francie Barrett. Saviours is more representative of what documentary writer Michael Rabiger terms the 'walled city' film in serving as a kind of microcosm of the wider society, not by some kind of tedious metaphoric overstatement, but because the subject offers it. Shot over an extended period at St. Saviours
Olympic Boxing Academy in Dublin's North inner city, the film charts the sporting highs and lows of promising fighters Dean Murphy, Abdul Hussain, and Darren Sutherland. Even the national and ethnic blend is fascinating (and incidental). Murphy is a classic inner city lad from Dominick Street fitting a classic profile of a hard working youth literally fighting his way towards a brighter future. Sutherland also fits the profile to a degree, but his West Indian roots and racial mixedness posits a combination of the new and the old again without need to exaggerate or make grand claims for significance. Hussain's is an even more interesting case as far as profiling contemporary Ireland is concerned. A Ghanean asylum-seeker, Hussain's struggle to remain in Ireland provide the film with its most powerful documentary moment. In the course of the film Abdul receives notification from the State regarding his status, and in an exquisitely painful scene, he initially leaps for joy believing it to be positive, only to realise upon re-reading that his application has been denied. Nolan and Whitaker shoot the scene with the impassive patience of nature photographers. Clearly involved with their subject and shooting hand-held, there is an intimacy to the scene that comes from Hussain's clear connection with the crew. Yet his moment of triumph turned to anguish is observed by the same camera, and as he turns to the crew, rereading, realising, the film needs to make no formal statement to present a powerful sense of the conflicts that define contemporary nationality (and ethnicity) in Ireland.

On the whole the film achieves that intimacy and focus associated with sports documentaries whose sense of the sport is strongly developed enough to allow such a 'walled city' level of metaphor to emerge naturally. It is easy to see the ebb and flow of familiarity with the camera among the participants, and there is a strong sense that this film is both part of what it is filming and yet involved in 'representing' it almost in the sense of advocacy of which Bill Nichols writes in defining the word as it pertains to documentary film. As noted, the film also takes on added significance after the fact first of all in that Darren Sutherland's success at the 2008 Olympics (where he won a Bronze Medal for Ireland) just after the film's production and 
then his subsequent tragic death merely proved an extension of what the film had seen and shown. Throughout the film, Sutherland's waxing and waning commitment to his boxing was part of his dramatic story arc, and there was a strong sense of conflict and crisis about his decision, as if something deeper than simply time was involved in his occasional disappearance from training and seeming refusal to push forward. Yes to some degree the reading of this sense of crisis depends on our subsequent knowledge of his suicide, but again it is testament to Whitaker and Nolan's observational eye that the threads are there to be seen. As a film providing insight into the processes and nature of the sport that also proves a powerful register of the reality of life in Ireland viewed through this prism, Saviours is a noteworthy film in a way that Waveriders is not, and its sense of legacy runs deeper than a continuum of history towards an arc of national identity.

On the face of it, Sideline Productions' release of classic GAA matches on DVD would seem to provide the clearest inroad to a sense of both history and identity. Building on the success of their annual season summaries and several personality-based historical overviews of 'great moments' in GAA history, the unexpurgated release of complete Football and Hurling matches from the television age might well be reason for considerable excitement - a true documenting of the legacy of the GAA by the potential for immersion. So many summative releases are dogged by talking heads and snippet editing that they are both boring and frustrating, not least of all some of the company's previous releases, but a solid, sustained focus on a single important match - what an opportunity. In the end though, it is an opportunity lost as far as documentary is concerned. The DVDs, retailing at $€ 20$ each, feature nothing but a menu screen, and the footage of the matches is just that - from whistle to whistle, with no sense of the crowd, no contemporary scenes of prelude or conclusion, no halftime analysis from the archives, no context, no commentary. While there is absolutely a raw 'actuality' value to these moments in time being available, it is disappointing to find them floating so free of their conditions of production and reception that they come to have no meaning at all, and at $€ 20$, not cheaply. That said, this writer made a gift of a set of them charting the great Dublin v. Kerry battles of the late 1970s and early 80s to his father, who was thoroughly pleased and enchanted. This does make you reflect on what we expect from our sporting past. Does the capacity to 'relive' the moment require input from memory and the collective conscious, or does it behoove the producers of these valuable records to help us somehow. Are the formal stylings of historical overviews (talking heads, edited sequences, intrusive soundtracks) inherently so destructive of the moment itself that there is greater value to this unedited and downright unexciting presentation of important moments in sporting history?

If Waveriders, Saviours, and the "GAA on DVD” releases tell us anything as a collective group of non-fictive engagements with Ireland the Isle of Sport, it is that the potential for reflection (both conscious and unintentional) is very great when dealing with sporting topics. They also show that sport has become a site wherein which change, progress, and evolution are visible, complete with the problems thrown up by these processes. The image of the Clergy may no longer be as broadly applicable to the documentary image of "the green and friendly isle of Ireland" as it was in 1960, but sporting endeavour still represents a significant face of Irish cultural identity on the world stage, and as Waveriders and Saviours continue in international distribution via festivals and DVD distribution, it seems unlikely that the result will always be what you expected.

Harvey O'Brien teaches Film Studies at University College Dublin. He is the author of The Real Ireland (2004) and co-editor of Keeping it Real (2004). He is co-editor of Film and Film Culture, the Irish journal of international film studies and a member of the Board of the Irish Film Institute. Forthcoming publications include Action Movies: The Cinema of Striking Back (Wallflower, 2011). 
Savage Sounds (Brendan Muldowney, 2009)

\section{Maria O’Brien}

Savage, the debut feature by Brendan Muldowney, follows a photographer, Paul (Darren Healy), who is brutally mugged in an apparently random attack, and his eventual descent into brutal revenge killing. The soundtrack is by the well established Irish composer of film music Stephen McKeon. Described by one reviewer as "utilising a brilliantly insidious sound design" the use of low tones and discordant strings seems to tie in with the film as a generic revenge thriller.

But why should these low tones portend a threat? Kassabian (2001) acknowledges empirical research on the cultural assumptions of meaning of music, questions these assumptions, but acknowledges that within a competent Western audience, these cultural assumptions generally work. It is beyond the scope of this essay to prove or question these assumptions in depth, but I want to acknowledge these assumptions and get meaning out of the associations.

The film score uses cultural standards to give meaning. McKeon uses violins, violas, cellos, to create an instrumental score that meanders through the low register, occasionally soaring to heights when apt, like when featuring Paul's love interest, Michelle (Nora Jane Noone). There is also much use of synthesized music, utilizing low drones, discordant tones, and sudden clashes, mixed with the sounds of the street, which creates an overall menacing effect. He also uses some affiliating identifications (Kassabian, 2001) deploying two Chopin nocturnes to great effect, evoking sympathy in the audience for Paul's mental and physical anguish. To generalize, certain cadences and low noises are taken to be threatening, while ethereal music is generally associated with the female. We must acknowledge that this interpretation is culturally coded for an audience with musical competence to interpret it as such. Savage, in addition to exploiting and reinforcing such cultural norms, uses environmental sounds - part of the soundscape which is not usually seen as part of the musical score - in a similar way. Discussions of film sound tend to talk reductively about diegetic and non-diegetic music, dialogue and soundtrack as if these are all separate discrete elements. While this may be the way a film is compiled, the audience does not perceive the layering of the sounds, but experiences it as an overall effect, not distinguishing sound from music. R. Murray Schafer (2004) coined the term "soundscape" to describe what he calls "the vast musical composition which is unfolding about us ceaselessly"; environmental noises which we should appreciate and understand and not control and eliminate as a form of pollution.

In Savage, in contrast to traditional practice, the music drives the simplistic revenge narrative. The use of music in a film is usually seen as subordinate to the visual narrative. Claudia Gorbman's “Unheard Melodies” (1987) illustrates the lack of importance paid to music which was seen as a ("silent") accompaniment to the visual narrative. Film was, in the past, considered a primarily visual art and sound, the poor relation, seen as little more than a superfluous accompaniment. Altman (1985) proposes a justification for this visually oriented analysis by calling cinema a child of Renaissance perspective. Gorbman says that the audience will not usually notice the music unless it interrupts the story. But in Savage, unusually the music and the use of sound, in fact the overall soundscape, drive the narrative, giving meaning to the visuals. 
The low hum of traffic permeates the soundtrack of Savage, with only occasional silence. Sirens puncture the soundtrack, unsettling the audience with their ubiquity. Occasionally the siren sounds increase in density to turn into the tinnitus that affects Paul after the mugging, overwhelming the power of the visual. In one early scene, when Paul is in his apartment, the sirens get louder and louder, drowning out his telephone conversation, infringing his sanctuary of the home. The composed music score uses a number of different approaches to create dissonance and an unsettling atmosphere, adding to the sense of foreboding permeating the film. A low regular thudding/thumping sound mimics the drone of traffic. The low drone of traffic can be interpreted ironically in a doctor's office, where the bland doctor suggests a gym and a good diet as a cure for Paul's problems. We see that the outside world, with its ubiquitous violence, won't go away. The violence is endemic to society.

Music is not a pure system, as Adorno has claimed, (Adorno quoted in Kassabian 2001) but bears ideologies. It establishes society while being constituted by it. Music is gendered, and this film's score plays along with this ideology by giving Michelle (Nora Jane Noone) a leitmotif of angelic, uplifting strings. At times the music chosen seems hackneyed. Michelle's leitmotif of angelic strings leads us to the obvious assumption that redemption is possible through her. But her leitmotif moves, and is subverted, through association with Paul in a scene where Michelle is not present. Near the end of the film, when he sees the men that assaulted him arguing in the alleyway, the angelic music usually associated with Michelle kicks in. Paul chases them and they seem to disappear leading us to question their presence. Were they in his head? The transference of her music to Paul's internal descent denies her potential as a saviour, there has never been any possibility of escape or of redemption because of society's ills.

The music echoes the morality of the film. We are not given an answer to the question of the level of acceptable violence. In one of the first scenes before his mugging, Paul takes a picture of two winos fighting, a picture which ironically is of no use to his editor because of its ubiquity.
The violence increases throughout the film, culminating in the horrific double murder by Paul. In one scene, when Paul is watching TV footage in his apartment, (journalist) Ian O'Doherty is being interviewed about the level of violence in society. Comically, in answer to a question by the interviewer about himself, he says "If someone breaks into my house, I'll kill them." He has been decrying the increased violence in society but then, deadpan, encapsulates the fundamental level of violence in society by implicating himself in it. Echoing this, the music does not provide finality. Unfinished cadences in McKeon's composed score leave us with no answers.

Heightened visceral noises are used throughout the film for effect. When we first encounter Paul's father being fed by the nurse, the sound of his eating draws attention to his weakened physical state. In the mugging, in the killing of the sheep by Paul in the otherwise bucolic countryside, and in the final brutal murder by Paul we hear the visceral sounds of knife on flesh. But there are no such heightened noises in the lovemaking with Michelle. So the lack of visceral sounds, where we would expect them, alerts us to the unreality and detachment of the Paul's world. We think that he might get redemption through the angelic figure of Michelle, but the lack of reality, emphasized by this lack of visceral sounds, in their encounter, means that we realise Paul is doomed to his violent fate.

In melodrama we expect resolution but Savage concludes in chaos. This is achieved in part through the soundscape of the film with the use of discordant tunes, the slippage of leitmotif, the drone of traffic, and heightened visceral sounds. The score in the scene where Paul walks through Dublin, before he is mugged, uses ethereal soaring strings to contrast with the violence of the late night city. We see fighting girls, pools of vomit, and the general detritus of a city at night. The strings are like unanswered questions, with no conclusion. Similarly, Savage uses its soundscape to show man's war with himself. In this the music echoes the morality of the film, which refuses closure. There is no finality, no redemption, and we are left in a moral grey area. 


\section{Works Cited:}

Altman, Rick. 1985. “The Evolution of Sound Technology”, Film Sound, Theory and Practice, ed. by Elizabeth Weis and John Belton, Columbia University Press.

Gorbman, Claudia. 1987. Unheard Melodies, Narrative Film Music, Indiana University Press.

Kassabian, Anahid. 2001. Hearing Film: Tracking Identifications in Contemporary Hollywood Film Music, Routledge.

Schafer, R. Murray. 2004. “The music of the environment”, Audio Culture: Readings in Modern Music, ed. by Christopher Cox and Daniel Warner, Continuum.

Maria O'Brien holds an M.A in Screen Studies from Goldsmiths, University of London, and is currently undertaking a Ph.D in Film Studies in Trinity College Dublin, focusing on Ang Lee as a transnational film-maker. 